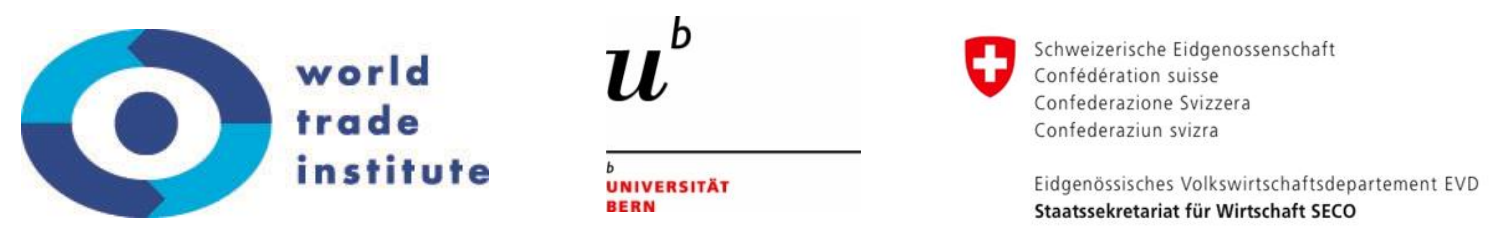

\title{
Promoting Logistics Providers Developing Countries: Proposals for Peru
}

\author{
Manuel Quindimil \\ Sub-Gerente, Área de Relaciones Gubernamentales y Legislativas \\ Cámara de Comercio Americana del Perú (AmCham Perú) \\ mquindimil@amcham.org.pe
}

This working paper provides a historical overview of the performance of logistics service providers, examining the characteristics of regulations governing logistics service providers, with emphasis on Peru. The paper also discusses the best practices implemented in a number of countries for promoting the integration of logistics operators, presenting a series of proposals for developing logistics service providers in Peru.

Research for this paper was funded by the Swiss State Secretariat for Economic Affairs under the SECO / WTI Academic Cooperation Project, based at the World Trade Institute of the University of Bern, Switzerland.

SECO working papers are preliminary documents posted on the WTI website (www.wti.org) and widely circulated to stimulate discussion and critical comment. These papers have not been formally edited. Citations should refer to a "SECO / WTI Academic Cooperation Project" paper with appropriate reference made to the author(s).

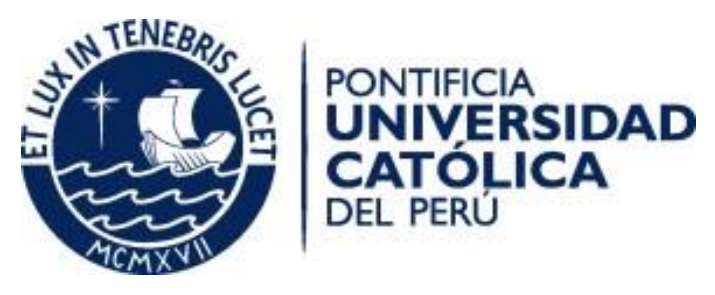




\section{INTRODUCTION}

In a context of evolving international trade norms, some disciplines have emerged, like trade facilitation and transportation, logistics, and connectivity development, which aim at expediting the flows of goods, services, ideas, and investments throughout global production chains. Trade facilitation is not limited to border barriers, but also includes "behind-the-borders" regulations. In this regard, the emergence of logistics as a key competitiveness element, and the need to promote connectivity, has taken centre stage in international trade policy.

Peru has high logistics costs, and therefore its exports lack the necessary competitiveness for accessing international markets. This has been a permanent problem, and only recently has the country begun to consider designing and implementing national logistics strategies.

One of the main obstacles facing Peru is the delay in putting in place an appropriate institutional framework for setting the national logistics plan in motion. This problem has seriously jeopardized the development of logistics services within the country.

In deepening the analysis of logistics providers, it is advisable to consider that, towards the end of the 20th century, the growing integration of logistics operators has generated a model of horizontal and vertical integration processes in the market for logistics service providers. Logistics service providers who used to supply their services in an independent and fragmented manner - currently in the process of disappearing - face competition, at the global and regional level, from great comprehensive logistics service conglomerates.

Peru's geographic location creates a natural advantage for developing these kinds of services. At the same time, if appropriate policies are not in place, this opportunity could be lost.

Section I of this study provides a historical overview of the performance of logistics service providers. Section II examines the characteristics of regulations governing logistics service providers, with emphasis on Peru. Section III discusses the best practices implemented in a number of countries for promoting the integration of logistics operators. Section IV presents a series of proposals for developing logistics service providers in Peru. The last section summarizes the conclusions. 


\section{FROM FRAGMENTATION TO INTEGRATION IN THE LOGISTICS SERVICE INDUSTRY}

\section{I.1. Focus of the analysis of logistics service providers}

One of the key components of a National Logistics System concerns the provision of logistics services. ${ }^{1}$ The latter include a wide range of activities, such as the transportation of commodities, intermediate goods, and final goods among suppliers, producers, and consumers. Its main elements are cargo agencies, multimodal transportation (using different means like air, sea, railway, and land transportation), storage, tracking and traceability, and customs dispatch. The logistics industry has expanded to include value added services, order processing, post-sale services, supply chain management, inventory management, and reverse logistics. ${ }^{2}$

Providers of logistics services are companies dedicated to supplying one or more logistics services with differing degrees of sophistication. As indicated by Isabel Agudelo, logistics operators are considered the same as logistics service providers. This study will use both terms interchangeably. ${ }^{3}$ Arturo Berrozpe Martínez points out that there are a number of terms that attempt to define external logistics service providers. He enlists the following: "logistic partnerships," "logistic contracts," "logistic operative partnerships," "distribution contracts," and finally the "3PLs" or "logistics operators" ("third party-logistics"), probably the most widely accepted term. ${ }^{4}$ The lack of a unique definition may be due to the historical evolution of the provision of logistics services, which transitioned from fragmented traditional logistics operations to integrated service providers. In this light, understanding the matter under study implies focusing more on the activities carried out by operators rather than the denominations that have emerged over time. Starting from this approach, it can be stated that currently a

\footnotetext{
1 A National Logistics System (SLN) can therefore be defined as an inseparable set of goods, produced within a national territory or abroad, that are mobilized between points of departure and destination via specific logistics services and using diverse infrastructure - logistics, transportation, and others - and processes. MARTINEZ RIVAS, M. (2015) Módulo 1: La Logística de Cargas y los Sistemas Logisticos Nacionales. Formulación y Gestión de Politicas sobre Transporte de Carga y Logística. First edition. Inter-American Development Bank and COSIPLAN, p. 34.

SLN supply has three main components. First, infrastructure, including different types of logistics infrastructure and transportation. Second, services, including different transportation, logistics, and value-added services. Third, support and facilitation systems for logistics activities. AGUDELO, I. (2015) Módulo 2: La Oferta - Los Componentes Básicos del Sistema Logístico Nacional. Formulación y Gestión de Políticas sobre Transporte de Carga y Logística. First edition. Inter-American Development Bank and COSIPLAN, p. 9.

2 A possible definition is that "inverse logistics deals with the recovery and recycling of hazardous containers, packings, and residuals; and with the return of inventory excesses, returned merchandise, obsolete products, and seasonal inventories. It also avoids reaching expiration of goods by selling them in higher-rotation markets". (Hortal, M. and Navarro, V. F., 2011)

${ }^{3}$ AGUDELO, I, op. cit., p. 12, p. 38.

${ }^{4}$ BERROZPE MARTÍNEZ, A. (2012) La Cadena de Valor de los Operadores Logísticos en España: Un Análisis Empírico, p. 45. Editor: Lulu.com (May 16, 2012).
} 
logistics operator is a company that provides management over the flow of goods and commodities between the initial and final consumption points. The provider can manage sea or air transportation, inventories, storage, packaging, security, internal transportation, and distribution of international shipments. Additionally, providers of logistics services are intermediaries within the supply chain that provide support, using their own assets and resources, in favour of other companies. Shippers may find it beneficial to use these intermediaries, as it allows them to focus on their main competences without having to deal with transportation or logistics issues. ${ }^{5}$

For greater conceptual clarity, transportation services will be distinguished from logistics services as such. Isabel Agudelo emphasizes that cargo transportation services are specifically dedicated to moving merchandise from one place to another. This service is part of the overall logistics chain, which aims at placing one or more products at the indicated moment and place, at the lowest logistics cost. Additionally, this author indicates that cargo transportation services are provided via different transportation modalities: land, sea or waterway, air, railway, and multimodal. In several instances, as sometimes logistics operators provide both cargo transportation and logistics services, it may be difficult to disaggregate both concepts. Despite this limitation, this study will analyse the development of logistics service providers excluding transportation service providers.

As indicated above, until the 1990s the provision of logistics services involved a number of participants specialized in a specific task and catering to different structured markets: international transportation, pre- and post-embarkation transportation, embarkation organization, and pre- and post-embarkation auxiliary services (loading/unloading services, storage services, cargo transportation services, etc. ${ }^{6}$ Industrial corporations launched production fragmentation towards the end of the 20th century due to a number of causes: a considerable increase in global trade, ${ }^{7}$ the expansion of information and communication technology (ICT) which resulted in a reduction in costs associated with communications and coordination activities - and the deregulation of transportation and communication services. This process, generated by developments in the global economy, resulted in the emergence of the concept of

\footnotetext{
${ }^{5}$ HICKSON, A., WIRTH, B. AND MORALES, G. (2008). Supply Chain Intermediaries. University of Manitoba Transport Institute. Manitoba, p. 4. Downloaded 02/13/17. https://umanitoba.ca/faculties/management/ti/media/docs/scIntermediariesfinalwithcover(1).pdf 6 FRÉMONT, A. (2009) Empirical Evidence for Integration and Desintegration of Maritime Shipping, Port and Logistics Activities. Joint Transport Research Centre. January 2009. Discussion Paper No 2009-1-OECD/ITF, p. 6. Downloaded 02/13/17 http://www.itf-oecd.org/sites/default/files/docs/dp200901.pdf

7 This was due basically to the elimination of tariff and non-tariff barriers promoted on two fronts: WTO and regional FTAs.
} 
global logistics. Peter Rimmer mentions that global logistics are nothing else than the result of the greater regional economic integration that emerged in the 1990s. ${ }^{8}$ Issa Baluch indicates that global logistics called for a greater reduction in costs; and that the way to accomplish this was through a more efficient management of the supply chain. By concentrating on their core business, greater efficiency was achieved by outsourcing logistics management. ${ }^{9}$ Logistics outsourcing activities carried out by companies specialized in providing logistics services brought about the emergence of new comprehensive logistics operators.

A similar process has taken place in the regulation of contracts between producers, transportation companies, and buyers. Currently the most influential intermediaries in international trade operations are freight forwarders. The latter may participate in a transportation contract between a company that sends cargo and a transportation company as agent to the sender, not the transportation company. However, there are also cargo agents that broker the services of transportation companies, organize transportation contracts on behalf of transportation companies, and issue and sign the transportation documents. Additionally, some cargo agents actually offer transportation services and execute them partially, or outsource their execution entirely, in which case it is quite difficult to distinguish them from transportation companies. ${ }^{10}$

\section{I.2. Historic evolution of the functions of logistics service providers}

\section{I.2.1. Sea cargo}

Logistics service providers for sea cargo are port operators, maritime agencies, loading/unloading companies, pilotage and towage companies, provisioning service providers, cargo agents, customs agents, warehouse operators, and transportation companies.

Traditional cargo movement was carried out as follows: port authorities temporarily stored the cargo within their own premises and provided crane cargo handling services. Maritime lines focused on providing international transportation services, where their responsibility started at the cargo port and ended at the port of arrival. Additionally, land operations for maritime lines

\footnotetext{
${ }^{8}$ RIMMER, P. (2014) Asian-Pacific Rim Logistics. Global Context and Local Policies, p.p. 32-33. Edward Elgar Publishing, Cheltenham, UK-Northampton, MA, USA.

${ }^{9}$ The document can be downloaded from:

http://www.elleryfreight.co.nz/files/links_sources/baluch_freightorward_role.pdf.

The document was consulted on August 11, 2016.

10 GUZMÁN ESCOBAR, J. (2005) El Agente de Carga REVIST@e - Mercatoria Volume 4, Number 1 (2005), p. 3.
} 
were carried out by maritime agents. The latter were in charge of cargo-related services, but on behalf of their principals, the shipping lines. Regarding export activities, maritime agents promoted and commercialized shipping lines' services, signed freight and transportation contracts, collected freight payments, and issued and managed embarkation documents. Concerning imports, these logistics operators organized the delivery in line with transportation documents, including collecting remaining freight payments and securing the interest of their principals in case of cargo loss/damage. For their part, freight forwarders ran cargo brokerage and ship chartering operations as independent third parties. Simultaneously, they provided pier services as companies authorized by the port authority for handling cargo. These companies were in charge of loading, unloading, and storing operations for the entrance and exit of merchandise from land transportation companies. The handling of cargo within the pier also involved longshoremen, in charge of loading/unloading cargo on behalf of loading and transportation companies or their agents. Procedures associated with customs dispatch were done by customs agents. Finally, national land or railway transportation companies carried load to their final customers. ${ }^{11}$

In view of the traditional segmented approach to the provision of logistics services, most analysts studied each link in the transportation chain in detail. The University of Manitoba's Supply Chain Intermediaries Study (logistics service providers) classifies as traditional services those provided by customs and cargo agents. Customs agents' typical functions were releasing imports and dispatching exports; obtaining and preparing the necessary documentation and information for dispatching goods; keeping the documentation; and resolving any dealings with customs after the payments of customs duties. ${ }^{12}$

For their part, freight forwarders were in charge of negotiating and organizing all matters related with transportation; coordinating the movement of goods until arrival at their final destination; preparing the necessary documentation, and providing advice on packaging, labelling, and marking of goods. Services provided by cargo agencies or freight forwarders are defined by the International Federation of Freight Forwarders Associations (FIATA) as services of any kind relating to the carriage, consolidation, storage, handling, packing or distribution of the goods as well as ancillary and advisory services in connection therewith, including but not limited to

11 SCHRAMM, H.-J. (2012) Freight Forwarder's Intermediary Role in Multimodal Transport Chains, p.p. 55-56-57. Contributions to Management Science, DOI 10.1007/978-3-7908-2775-0 1, C) Springer-Verlag Berlin Heidelberg 2012.

${ }^{12}$ HICKSON, A., op. cit. p. 4. 
customs and fiscal matters, declaring the Goods for official purposes, procuring insurance of the Goods and collecting or procuring payment or documents relating to the goods. ${ }^{13}$

Referring to a study by Hans-Joachim Schramm, Watanuki points out that the legal status of freight forwarders differs according to the functions they perform. The traditional role of a freight forwarder is that of an agent in charge of coordinating and assisting in the transportation of merchandise. Such operators become intermediaries between the sender-receiver and the transportation company. Under such arrangement, freight forwarders are not responsible for merchandise loss/damage. At the same time, if freight forwarders acts as principals, they contract a transportation company and a client, respectively. This makes freight forwarders responsible for the duration of the journey. ${ }^{14}$

An issue that also creates confusion is the existing regulation for freight forwarders in different jurisdictions. There are many countries that do not legally recognize freight forwarding as an industry in its own right; i.e., there are no laws or norms governing or defining their activities. In these cases, it is quite difficult to discern door-to-door services throughout the supply chain, in turn resulting in a fragmented notion of logistics operators. Additionally, in some countries there are voluntary associations that regulate such activities via General Terms and Conditions, which stipulate the duties and responsibilities of freight forwarders. In sum, in some jurisdictions there are specific norms for regulating the activities of freight forwarders, while in others they are not explicitly defined. ${ }^{15}$

Moving on to a different issue, storage services are the next link in the supply chain. They can be provided in the form of different storage categories. A warehouse is a building especially designed for receiving, storing, handling, reconditioning, and delivering goods. The main functions of warehouses are: i) balancing supply/demand differences; ii) reducing transportation costs; and iii) conditioning goods prior to delivery to the final client. ${ }^{16}$

Depending on whether the merchandise is bound for a deposit customs regime, where import tariffs are suspended, storage services will be deemed authorized or unauthorized by customs.

\footnotetext{
13 FIATA (International Federation of Freight Forwarders Associations) model norms for freight forwarding services, article 2. Document downloaded on May 18, 2016.

http://www.panalpina.com/content/www/esp/en/home/terms-and-

conditions/_jcr_content/contentParSys/download/downloadList/normas_modelo_de_la_.spooler.download/1401 27\%20FIATA_Spanisch\%20Spain.pdf.

${ }^{14}$ WATANUKI, M. (2015) Review of Logistics Service Regulations for Freight Forwarding Business. What should be addressed for Better Logistics Regulatory Framework? pp. 12-13. Policy Research Working Paper No. 7401, World Bank Group.

15 Ibidem.

${ }^{16}$ AGUDELO, I, op. cit., p. 12, p. 23.
} 
They can also be classified as public or private. Public storage corresponds to companies that receive merchandise from different clients. Private storage is a division of a company dedicated mainly to an activity different from storage.

Companies dedicated to delivering loading/unloading services and those dedicated to internal transportation may, depending on the organization of the different logistics service providers, also provide logistics cargo services.

The accelerated development of logistics at the global level since the 1990s also brought about a change in the management of the sea transportation industry. In the new context, cargo senders are increasingly requesting door-to-door services, which has a strong impact on the sea transportation industry.

Due to a reduction in profit margins for maritime freight, shipping lines expand their business beyond maritime transportation into cargo handling or land transportation. Along these lines, some shipping companies develop such activities via their own maritime agencies or subsidiaries, created for this purpose to avoid losing control of their marketing strategies. A new development is that shipping lines offer door-to-door and logistics services to clients generating large cargo volumes. Such market shifts have curtailed the role of maritime agents and freight forwarders, who have been absorbed by maritime lines or have been forced to diversify as logistics operators, integrators, or merchandise consolidators (generically known as non-vessel-operating common carriers, NVOCCs). ${ }^{17}$ For their part, land transportation companies either provide merchant

\footnotetext{
${ }^{17}$ Non-vessel operating common carriers (NVOCCs) are companies dedicated to merchandise groupage and maritime transportation. The main characteristic of NVOCCs is that they do not possess transportation ships, but rather reserve space on ships from and agent or operator, and use it for transporting their clients' merchandise. Additionally, they process all the necessary documentation, issue their own invoices, and take responsibility for the shippings.

The main function of NVOOCs is merchandise consolidation; i.e., they group merchandise from several importers/exporters in the same container. Many companies do not have the necessary resources (or do not need) to transport enough merchandise for filling a container. Maritime groupage companies are in charge of filing containers with merchandise from several companies.

The advantage of this service is that these companies only transport what is strictly necessary, at a much lower cost than renting a whole container.

Terminology of maritime transportation: ¿What is an NVOCC? Thursday, March 28, 2013.

AGC Newtral website, consulted on August 10, 2016.

http://www.agcnewtral.com/noticias/i/276/180/terminologia-del-transporte-maritimo-que-es-un-nvocc
} 
haulage for a shipper ${ }^{18}$ or act as the latter's cargo agents; or become agents to shipping companies in the case of carrier haulage (transportation of maritime transporters). ${ }^{19}$

With the port privatizations and the appearance of private port terminals, maritime lines either merged with other maritime lines or focused on logistics management for all handling and temporary cargo storage operations. They have integrated all cargo handling operations previously performed by companies and longshoremen authorized by port authorities. Port terminals, many of them operated by private companies, are specializing as container terminals, serving a single shipping line (or a strategic partnership of shipping lines) under and exclusive contract.

This new model creates horizontal and vertical integration processes in the marketing for logistics service providers. Horizontal integration translated into the consolidation of large shipping lines through partnerships, absorptions by competing companies, and internal growth. This process also took place in the markets for companies dedicated to cargo handling and freight forwarders. The development of multimodal transportation facilitated vertical integration by promoting the need for a single multimodal operator. The latter's objective is organizing door-to-door transportation, which is no obstacle for sub-contracting a specialist in one function within the transportation chain. As a result, maritime agency, cargo handling, international transportation, domestic land transportation, cargo agency, and customs agency activities are developed by a single logistics operator.

This process started in Peru towards the beginning of the century with the operation of port terminals by private companies, particularly in the port of Callao. The latter has experienced a vertical integration process -via ownership links and contractual arrangements between shipping lines and all other participating companies - whereby it is possible to provide ports with the logistics service chain wholly or partially. Most have contracts with maritime agencies and storage terminals; but, in addition, some are integrated with other maritime operators. Some horizontal concentration has also taken place via mergers and acquisitions among shipping lines. ${ }^{20}$

\footnotetext{
18 Inland transport of cargo in containers arranged by the Merchant. It includes empty container-moves to and from hand-over points in respect of containers released by the Carrier to Merchants. Note: Carrier's responsibility under the Bill of Lading does not include the inland transport stretch under Merchant Haulage.

19 The inland transport service, which is performed by the sea-carrier under the terms and conditions of the tariff and of the relevant transport document.

20 APOYO CONSULTORÍA. (2015) Estudio sobre la medición del grado de competencia intra-portuaria en el terminal portuario del Callao. Second Deliverable. Prepared for OSITRAN. April, 2015, p. 146. Downloaded 02/10/17
} 


\section{I.2.2. Air Cargo}

In the case of air cargo movement, the main agents providing services to aircraft are cargo terminals, temporary warehouses, and air cargo agents. The development of air cargo service providers goes back to the 1944 Convention on International Civil Aviation. The latter established the regulation of paid air transportation via bilateral government agreements. This system was created at a moment when almost all airlines were flag carriers and the air cargo industry was incipient. The bilateral agreements established airlines' traffic rights, tariffs, and the number and frequency of flights. ${ }^{21}$ This regulatory framework was overly restrictive: foreigners were excluded from participating in the control of national airlines; airlines were not allowed to diversify into complementary air cargo activities (on-land assistance services include on-ramp handling, package delivery, and storage) like land transportation and storage. Moreover, national legislations established restrictions for on-land assistance to certain companies or airport authorities, or it could not be provided by airlines. ${ }^{22}$ Participants in the air cargo transportation chain were independent, did not operate jointly, and had little communication and coordination with each other. ${ }^{23}$

This operating system started to change since the deregulation of the U.S. airline industry at the end of the 1970s. The reform prompted the establishment of bilateral open skies agreements, which contributed significantly to the liberalization of air services.

Additionally, in recent years the traditionally fragmented nature of air transportation companies has experienced considerable changes. Just-in-time production, shorter product life cycles, and technological advances (like real-time reservation and follow-up) have resulted in a reorganization of the industry towards structures that are more integrated and linked to on-land assistance services. The greatest challenge facing the traditional air cargo system has been the rapid expansion of integrated service providers. Under the traditional regulatory system, one single delivery was managed by several airlines, transportation companies, customs agents, warehouse operators, and truck companies. Express companies have prospered, thereby

https://www.ositran.gob.pe/joomlatools-files/docman-files/RepositorioAPS/0/0/par/000001-

TEMP/CONSULTAS/02-\%20ESTUDIO\%20DE\%20APOYO\%20CONSULTORIA\%20-PARTE\%201.pdf

${ }^{21}$ GELOSO GROSSO, M. \& SHEPHERD, B. (2010) Air Cargo Transport in APEC: Regulation and Effects on

Merchandise Trade. Journal of Asian Economics Volume 22, Issue 3, Pages 203-266 (June 2011)

22 Ibidem.

23 SCHRAMM, H.-J. (2012), op. cit. 
reducing this complexity by integrating air and land operations performed by airlines, transportation companies, and auxiliary service providers. ${ }^{24}$

Within the air cargo logistics chain there was a distinction between land and transportation operations endorsed by the IATA agency system.

In consequence, the air cargo supply chain is now the result of a combination of interconnected elements, locations, procedures, and information exchanges for transporting cargo via air from origin to destination. ${ }^{25}$ The consignor (the person who initiates the transportation or movement of merchandise) and the consignee are at each end of the chain.

Airports act as facilitators within the air cargo supply chain by providing the necessary infrastructure and facilities for ensuring fluent commerce across cargo transportation companies. ${ }^{26}$ Airport operators are the entities responsible for securing a safe airport infrastructure. They may also be responsible for providing cargo services at the airport.

Airlines or air transportation companies provide merchandise transportation services by air. A transportation contract links an aircraft operator with the relevant contracted parties for providing reliable and safe cargo and mail transportation from one location (the departure airport) to another (the destination airport). Air cargo may be transported on passenger aircraft, dedicated cargo aircraft, or a combination of both. As express transportation companies gather in a single company or conglomerate the functions of broker, transporter, freight consolidator and consignor, scale service provider, and aircraft operator, they are sometimes labelled as "integrators".

Freight forwarders (freight consolidators and consignors) are part of the transportation logistics process within the supply chain. Their main role is ensuring that air shipments are ready for transportation by aircraft operators (airlines). Their activities may include grouped cargo delivery, as required. They can manage the preparation, storage, transportation, and final delivery of merchandise within the supply chain, including the processing of documents and relevant facilitation operations. The services provided by a freight consolidator and consignor may

\footnotetext{
${ }^{24}$ GELOSO GROSSO, M. (2010), op. cit. p. 10.

${ }^{25}$ OACI-OMA. (2013) El transporte mundial de la carga aérea. Cadena de suministro segura para la carga aérea y el correo y directrices en materia de facilitación, p. 4. Downloaded 02/13/17.

http://www.icao.int/Security/aircargo/Moving\%20Air\%20Cargo\%20Globally/ICAO_WCO_Moving_Air_Cargo_ es.pdf

${ }^{26}$ Ibidem, p. 26. Downloaded 02/13/17.

http://www.icao.int/Security/aircargo/Moving\%20Air\%20Cargo\%20Globally/ICAO_WCO_Moving_Air_Cargo_ es.pdf
} 
include grouped delivery, storage, handling, packaging, or delivery of merchandise. A freight forwarder generally reserves and contracts, on behalf of an air cargo consignor, an aircraft operator under a transportation service contract from the departure airport to the destination airport. Freight forwarders' main responsibility is safeguarding the interests of their clients (the consignors or shippers). Grouping and delivery of cargo implies working closely with airlines to secure space on aircraft for accommodating deliveries ready for transportation. The latter is arranged via transportation contracts and the issuance of air waybills. ${ }^{27}$ On-land assistance service providers are sub-contracted and operate on behalf of freight forwarders and/or airlines when the latter do not own the necessary facilities. Their services may include providing storage for the admission, handling, preparation, and the labelling of cargo and mail, as well as loading/unloading, transit, and storage. The providers of these services are responsible for operational activities in line with the instructions provided by freight forwarders and/or airlines. Once ready for delivery, the freight forwarder dispatches the cargo and indicates the on-land service provider how to deliver it to the aircraft operator. On-land service providers are located at airport offices, usually the aeronautical section or the limit between the public and aeronautical sections, although sometimes they are located in the public section. ${ }^{28}$

These modalities are also employed in Peru. The delivery of storage services for cargo unloaded at Jorge Chávez International Airport is concentrated in just two companies.

\section{I.3. The Role of Third-Party Logistics Providers (3PLs)}

As explained in the previous sections, there has been a transition from the provision of fragmented logistics services to outsourcing logistics management in a comprehensive manner. Along these lines, logistics services may be provided by second, third, fourth, or fifth logistics parties ((2PLs, 3PLs, 4PLs, and 5PLs). As the latter have become increasingly integrated, currently logistics service providers not only focus on operating a fleet of vehicles for

\footnotetext{
${ }^{27}$ Ibidem, pp. 5-6. Downloaded 02/13/17. http://www.icao.int/Security/aircargo/Moving\%20Air\%20Cargo\%20Globally/ICAO_WCO_Moving_ Air_Cargo_es.pdf

${ }^{28}$ Ibidem, p. 6. Downloaded 02/13/17.

http://www.icao.int/Security/aircargo/Moving\%20Air\%20Cargo\%20Globally/ICAO_WCO_Moving_Air_Cargo_ es.pdf
} 
transporting and delivering goods, but also provide management and business services related with information technology (IT) consultancy. ${ }^{29}$

The Council of Supply Chain Management Professionals (CSCMP) mentions that supply chain management implies cooperation and coordination among all participants in the chain: providers, intermediaries, and clients. The CSCMP also indicates that intermediaries are key to promoting such cooperation and coordination. ${ }^{30}$

Andrés Castellano Ramírez explains that freight forwarders were among the participants that expanded their value-added services within the logistics chain. Many freight forwarders transitioned into 3PLs, 4PLs, and 5PLs. The author emphasizes the evolving characteristics of trade, which calls increasingly for dynamism, speed, and lower costs in the transactions between participants. This has driven freight forwarders to seek steadily to accommodate market demands for greater efficiency and coordination within the supply chain. Moreover, he stresses that outsourcing may be carried out via different types of logistics operators: 1PLs, 2PLs, 3PLs, 4PLs, and 5PLs. ${ }^{31}$

\footnotetext{
${ }^{29}$ EDER, T. (2015) Logistics Services. Chapter 3, in U.S. Commission, Recent Trends in U.S. Services Trade: 2015 Report, p. 54. May 2015, Publication Number: 4526, Investigation Number: 332-345. Downloaded 02/13/17 https://www.usitc.gov/publications/332/pub4526.pdf

${ }^{30}$ COUNCIL of SUPPLY CHAIN MANAGEMENT PROFESSIONALS, Glossary of Terms; consulted 02/16/17.

http://cscmp.org/imis0/CSCMP/Educate/SCM_Definitions_and_Glossary_of_Terms/CSCMP/Educate/SCM_ Definitions_and_Glossary_of_Terms.aspx?hkey=60879588-f65f-4ab5-8c4b-6878815ef921

"Supply Chain Management encompasses the planning and management of all activities involved in sourcing and procurement, conversion, and all logistics management activities. Importantly, it also includes coordination and collaboration with channel partners, which can be suppliers, intermediaries, third-party service providers, and customers. In essence, supply chain management integrates supply and demand management within and across companies. Supply Chain Management is an integrating function with primary responsibility for linking major business functions and business processes within and across companies into a cohesive and high-performing business model. It includes all of the logistics management activities noted above, as well as manufacturing operations, and it drives coordination of processes and activities with and across marketing, sales, product design, finance and information technology.
}

HICKSON, A., (2008), op. cit. p. 4.

${ }^{31}$ Blog Cibeles Logistics, consulted on May 18, 2016, http:// cibeleslogistics.blogspot.pe/2013/07/tipos-de-

operadores-logisticos.html

\section{PL - First Party Logistics}

Service providers that supply only merchandise transportation to organizations.

They are a first step in outsourcing activities that are not part of the main business. Transportation is one of the main services to be outsourced, given the wide supply in the sector and the savings in costs, added expenses, maintenance, and insurance. There is an ever-increasing specialization and organizations seek speed and security in deliveries.

\section{PL - Second Party Logistics}

In this second level, providers supply a mix of merchandise transportation and storage. It optimizes the flow of materials by combining two complementary services.

\section{PL - Third Party Logistics}

These providers are in charge of all or almost all logistics operations. They seek global solutions by specializing in the integration and customization of the following services: storage, inventory management, preparation of orders, 
The CSCMP defines Third-Party Logistics Providers (3PLs) as firms that provide multiple logistics services to clients. In general, such services are integrated or bundled by the provider. 3PLs may or may not use their own resources when providing such services. ${ }^{32}$

3PLs added storage, cross-docking, ${ }^{33}$, and distribution services to those typically provided by freight forwarders. Moreover, they are responsible for tracking shippings on behalf of their clients. The service portfolio is based on assets, and knowledge, with emphasis on the use of technology.

4PLs (Fourth-Party Logistics Providers) come next in degree of logistics operation outsourcing. They are also known as lead logistics integrators or lead logistics providers. Besides taking on the duties of 3PLs, they perform a more strategic function. They focus on the management and improvement of their clients' supply chain. 4PLs further integrate the supply chain by assembling and managing resources, capacities, and technologies together with those from complementary service providers to create comprehensive supply chain solutions. Typically, 4PLs do not have

and merchandise transportation. Support from a 3PL operator ensures service customization by seeking optimal logistics solutions tailored to an organization's needs.

\section{PL - Fourth Party Logistics}

The difference with 3PLs is that these providers bring together the organization and different logistics service providers. 4PLs manage the whole supply chain, including clients and providers. Using 4PLs implies outsourcing the whole chain, thereby saving costs and centralizing operations in one single provider that manages all processes.

CASTELLANO RAMÍREZ, A. (2015). Logística Comercial internacional, p. 292. Barranquilla: Editorial Universidad del Norte, reprint, 2015.

32 Third-Party Logistics (3PL): Outsourcing all or much of a company's logistics operations to a specialized company. The term "3PL" was first used in the early 1970s to identify intermodal marketing companies (IMCs) in transportation contracts. Up to that point, contracts for transportation had featured only two parties, the shipper and the carrier. When IMCs entered the picture-as intermediaries that accepted shipments from the shippers and tendered them to the rail carriers - they became the third party to the contract, the 3PL. Definition has broadened to the point where these days, every company that offers some kind of logistics service for hire calls itself a 3PL. Preferably, these services are integrated, or "bundled," together by the provider. Services they provide are transportation, warehousing, cross-docking, inventory management, packaging, and freight forwarding. In 2008 legislation passed declaring that the legal definition of a $3 \mathrm{PL}$ is "A person who solely receives, holds, or otherwise transports a consumer product in the ordinary course of business but who does not take title to the product."

Third-Party Logistics Provider: A firm which provides multiple logistics services for use by customers. Preferably, these services are integrated, or "bundled" together by the provider. These firms facilitate the movement of parts and materials from suppliers to manufacturers, and finished products from manufacturers to distributors and retailers. Among the services which they provide are transportation, warehousing, cross-docking, inventory management, packaging, and freight forwarding.

\section{${ }^{33}$ Cross-docking}

Cross-docking is a logistics technique whereby storage time is non-existent or very limited. It involves transferring shipments from the transportation means on which they arrive to another one on which they will depart, without need for storage. This modality is in line with the Efficient Consumer Response approach, which seeks higher efficiency throughout the supply chain. Cross-docking implies synchronizing the arrival/departure of merchandise through the following activities:

- Pre-distribution. Providers prepare the merchandise to be delivered.

- Receipt of merchandise.

- Capture of information. Necessary for an appropriate merchandise control.

- Re-packaging, cargo consolidation, and merchandise departure.

Website: "Supply Chain Challenges", consulted on May 19, 2016. http://retos-operacioneslogistica.eae.es/2014/10/el-cross-docking-en-la-gestion-de-proyectos-logisticos.htm 
physical assets: their competitive edge comes from knowledge and technological development. Additionally, 4PLs manage other intermediaries through the supply chain.

Currently 5PLs have the highest degree of outsourcing. Like 4PLs, 5PLs do not have assets of their own; furthermore, they focus on strategic services associated with the management of the supply chain. They differ from 4PLs in the use of technology and information in the discharge of their duties.

Measured in millions of dollars in gross revenues, the ten top 3PLs are DHL Supply Chain \& Global Forwarding (Germany), Kuehne + Nagel (Switzerland), Nippon Express (Japan), DB Schenker Logistics (Germany), C.H. Robinson Worldwide (U.S.), Hyundai GLOVIS (South Korea), CEVA Logistics (Netherlands), UPS Supply Chain Solutions (U.S.), DSV (Denmark), and Sinotrans (China). ${ }^{34}$ In terms of growth opportunities in the service provision market, Armstrong \& Associates underscore China, with a 10.8\% expansion in 2010-2012, followed by South America and Asia-Pacific excluding China and Japan (6\% and 6.2\% respectively over the same period). ${ }^{35}$ Within an attractive market like South America, Peru is positioned to attract investments from these global operators.

This transformation of logistics providers, especially freight forwarders, who gradually took on higher value-added activities in addition to their traditional functions, has not been captured by domestic legislations in a uniform manner. First, they lack a unified categorization of the legal regulation of freight forwarders. Maika Watanuki warns that, despite the definition proposed by FIATA, not all countries recognize the role of cargo agencies under the term "freight forwarding". "She cites the case of the U.S., where these operators are known as "non-vessel operating common carriers" (NVOCCs) ${ }^{37}$ or "ocean transportation intermediaries" (OTIs). ${ }^{38}$ In

\footnotetext{
34 ARMSTRONG \& ASSOCIATES, INC. (2014) Global and Regional Infrastructure, Logistics Costs, and Third-Party Logistics Market Trends and Analysis, January 2014.

35 Ibidem.

36 WATANUKI, M. (2015), op. cit. p. 7.

3746 CFR 515.2 - Definitions. Non-vessel-operating common carrier services refers to the provision of transportation by water of cargo between the United States and a foreign country for compensation without operating the vessels by which the transportation is provided, and may include, but are not limited to, the following:

(1) Purchasing transportation services from a common carrier and offering such services for resale to other persons;

(2) Payment of port-to-port or multimodal transportation charges;

(3) Entering into affreightment agreements with underlying shippers;

(4) Issuing bills of lading or other shipping documents;

(5) Assisting with clearing shipments in accordance with U.S. government regulations;

(6) Arranging for inland transportation and paying for inland freight charges on through transportation movements;

(7) Paying lawful compensation to ocean freight forwarders;

(8) Coordinating the movement of shipments between origin or destination and vessel;

(9) Leasing containers;

(10) Entering into arrangements with origin or destination agents;
} 
contrast, in other countries the duties performed by such operators are also known as freight forwarding, if only because there are overlappings between their functions. Another frequently used definition for cargo agencies is "multimodal transportation operators", established by the UN Convention on International Multimodal Transport of Goods (1980). ${ }^{39}$ Moreover, outsourcing of logistics and integration of different links within the supply chain, as a market development, has not been officially captured by domestic legislation in several countries. As a result, there are no regulations in place for 3PLs, 4PLs, and 5PLs.

In Peru, customs agents were the first to integrate different logistics services; e.g., by offering additional services like customs brokerage for cargo and transportation.

It is important to underscore that, as of the drafting of this study, Peru had no comprehensive legislation for logistics service providers. It was not until the past decade that Latin American countries saw the need to adopt public policies for improving the performance of logistics activities, thereby contributing to enhancing export competitiveness among the countries in the region. Therefore, there are no examples in the region for assessing the impact of implementing a logistics service policy.

\section{REGULATION OF LOGISTICS SERVICE PROVIDERS}

\section{II.1. Difficulties in regulating the industry}

Until not long ago there was no clear distinction between transportation and logistics services. The regulation of transportation services was a matter of significant concern to governments. Transportation systems were and are inextricably linked to economic development. Transportation policies are also associated with national security, airspace sovereignty, public

(11) Collecting freight monies from shippers and paying common carriers as a shipper on NVOCC's own behalf.

3846 CFR 515.2 Ocean transportation intermediary (OTI) means an ocean freight forwarder or a non-vesseloperating common carrier. For the purposes of this part, the term:

(1) Ocean freight forwarder (OFF) means a person that -

(i) In the United States, dispatches shipments from the United States via a common carrier and books or otherwise arranges space for those shipments on behalf of shippers; and

(ii) Processes the documentation or performs related activities incident to those shipments; and

(2) Non-vessel-operating common carrier (NVOCC) means a common carrier that does not operate the vessels by which the ocean transportation is provided, and is a shipper in its relationship with an ocean common carrier.

39 Article 1

DEFINITIONS

2. "Multimodal transport operator" means any person who on his own behalf or through another person acting on his behalf concludes a multimodal transport contract and who acts as a principal, not as an agent or on behalf of the consignor or of the carriers participating in the multi modal transport operations, and who assumes responsibility for the performance of the contract.

WATANUKI, M. (2015), op. cit. p. 7. 
safety, and environmental protection. Furthermore, governments must avoid monopolistic trends in all transportation activities. Finally, government intervention in transportation activities has limited private sector participation in such a strategic industry. On the contrary, until recently logistics was considered to be exclusively a business concern. ${ }^{40}$

Tomassian, Pérez Salas, and Sánchez indicate the presence of multiple policies and norms seeking to regulate and promote transportation activities. However, they lack a systemic and integrating vision that can create a coherent regulatory body and facilitate appropriate regulation and supervision. In Latin America, infrastructure and transportation policies have typically been treated in a dissociated manner and implemented unevenly across transportation activities (unimodal policies). ${ }^{41}$

Strict government intervention in transportation activities began to decline towards the 1980s with the beginning of liberalization and privatization processes. From then on, private operators typically manage state-owned ports and airports through concession contracts.

Additionally, due to evolving global conditions, especially in production and distribution systems - production fragmentation-, logistics became a central element in competitiveness across industries, as it is instrumental in planning, implementing, and controlling the flow of goods, services and information with an aim to meet consumer requirements effectively and efficiently. In consequence, over time the prevailing approach has shifted from a private business issue to an interest in improving competitiveness as a matter of national concern. In sum, the growing importance of facilitating the flow of goods and services as a key competitiveness element has turned logistics into a public policy issue.

From a legal point of view, the regulation of logistics services involves significant complexities. ${ }^{42}$ First, given the overlapping between policies for transportation and logistics activities, it is key to emphasize the multi-sectoral nature of the latter. Regulations for logistics services are dispersed over several government jurisdictions and their respective ministries, which hampers a comprehensive understanding of norms applicable to trade-related logistics operators. Watanuki cites the example of transportation companies, which must obtain licenses for their trucks and, at the same time, request customs to authorize their operations. Several public agencies enforce

40 SAVY, M. (2016) Logistics as a political issue, Transport Reviews, 36:4, 413-417, DOI: 10.1080/01441647.2016.1182793

41 TOMASSIAN, G., PÉREZ SALAS, G. y SÁNCHEZ, R. (2010) Políticas integradas de infraestructura, transporte y logistica: experiencias internacionales y propuestas iniciales. Serie Recursos Naturales No. 150, 14.

42 WATANUKI, M. (2015), op. cit. p. 7. 
their own norms on this sector, such as public safety and environmental protection regulations, among others. Watanuki concludes that it is necessary to avoid such abundant and diverse regulation enforced by a number of authorities and establish single-window procedures for logistics operators to improve transparency and compliance with norms. ${ }^{43}$

Peru lacks an updated legal framework for logistics service intermediaries. Many logistics operators are governed by legislation for port and other associated services (general, maritime, waterway, lake, and loading/unloading agencies) enforced by the Ministry of Transportation and Communications (MTC). ${ }^{44}$ A study by the Advanced Logistics Group criticizes this duplication of norms and the fact that there is no clear indication of which entity is in charge of regulating certain port services. Additionally, the minimum requirements established by the legislation have promoted informality in the provision of port services; and companies providing port services are often not clear about their roles and responsibilities vis-à-vis the authorities and consumers due to certain regulation voids. Also resulting from inappropriate regulation are the atomization, fragmentation, and low specialization of companies providing port services, as well as a lack of incentives for business consolidation, sufficient insurance for cargo damage, adequate performance, and transparency in the tariffs charged by different agents, among other problems. ${ }^{45}$

The competent agencies for regulating logistics service providers' activities in Peru are:

- Ministry of Transportation and Communications (MTC)

- Ministry of Economy and Finance (MEF)

- National Competitiveness Council (CNC)

- Ministry of Production (PRODUCE)

- Ministry of Trade and Tourism (MINCETUR)

- National Institute for the Defence of Competition and the Protection of Intellectual Property (INDECOPI)

\footnotetext{
43 Ibidem.

${ }^{44}$ Decreto Legislativo No. 707 (1991) declared as national interest the efficient, timely, swift, and inexpensive provision of services by general, maritime, waterway, and lake transportation agencies; and by cooperative loading/unloading companies. Decreto Supremo No. 010-99-MTC is the by-law for general, maritime, waterway, and lake transportation agencies; and for cooperative loading/unloading companies. Decreto Supremo No. 016-2005-MTC indicated that the procedures established by this norm, except those related with general agencies, are under the competence of the National Port Authority.

45 ADVANCED LOGISTICS GROUP (2009) Estudio 15: Estudio orientado a reglamentar la asignación de responsabilidades en servicios portuarios brindados a la carga. Proyecto UE-Perú/PENX. September 2009, p. 92. Dowloaded 02/10/17. http://ww2.mincetur.gob.pe/wpcontent/uploads/documentos/comercio_exterior/Sites/ueperu/licitacion/pdfs/Informes/140.pdf
} 
- Supervisory Authority for Infrastructure and Public Transportation (OSITRAN)

- Superintendence of Land Transportation of Passengers, Cargo, and Merchandise (SUTRAN)

- National Port Authority (APN)

- Private Investment Promotion Agency (Pro Inversión)

- National Superintendence of Customs and Tax Administration (SUNAT)

- Regional and Local Governments (Municipalities)

The primary obstacles facing these service providers are the countless procedures before a number of entities from different jurisdictions that they must complete before being allowed to operate. The red tape imposed by authorities at the local, regional, and central government levels creates too heavy an administrative burden for companies seeking to provide logistics services within the country. The latter include mandatory permissions by the National Institute for Civil Defence (INDECI) and the National Service for Agricultural Sanitation (SENASA); multiple operating licenses issued by all municipalities where logistics service providers operate; and other authorizations (e.g., for animal and vegetable sanitation, as required).

The National Export Plan (PENX) 2015- 2025, action line 3.4, mentions the need to improve the regulatory framework, optimize procedures, and promote technological solutions. It recognizes problems across industries identified while preparing the National Policy for the Modernization of Public Management, such as a deficient design of the organization and functions of public entities; inappropriate public service production processes; insufficient infrastructure, equipment, and logistics management; unsatisfactory human resource (HR) policy and management; limited assessment of results, impacts, follow-up, and monitoring of inputs, processes, products, projects, and activities; lack of systems and methods for managing information and knowledge; and weak inter-governmental, and inter-sectoral coordination. ${ }^{46}$

Even though the government has attempted to carry out a comprehensive administration simplification reform, the red tape involved in starting a business and obtaining an operating license continues to be a heavy bureaucratic burden for operators.

An example of the high operating costs created by over-regulation of logistics service providers is the levy of charges for "on-board sanitation control certificates" and "exemptions from on-

\footnotetext{
46 PLAN ESTRATÉGICO NACIONAL EXPORTADOR 2015- 2025, p. 67. Downloaded from the MINCETUR website on 01/02/17. http://ww2.mincetur.gob.pe/wpcontent/uploads/documentos/comercio_exterior/plan_exportador/Penx_2025/PENX_FINAL_101215.pdf
} 
board sanitation control certificates" imposed by the Maritime Sanitation Directorate of the Regional Government of Callao. The Peruvian Association of Port Operators (ASPPOR) pressed charges against them and obtained a declaration of illegality from the INDECOPI Tribunal; but the financial effort involved in the lawsuit implied a considerable over-cost to Peruvian logistics operators. ${ }^{47}$

Moreover, the logistics chain is very fragmented. Each link in the chain is subject to copious licensing for customs agents, transportation companies, warehouses, handling of hazardous merchandise, and safeguards against fire risks. This regulatory fragmentation jeopardizes the delivery of door-to-door services by international logistics operators.

Peru's customs legislation is a case in point. Title II of Peru's General Customs Law (Decreto Legislativo No. 1053) refers to international trade operators and managers or concessionaires of ports, airports, and land terminals. It is important to underscore that it was not until the enactment of new legislation in 2015 (Decreto Legislativo No. 1235) that managers or concessionaires of ports, airports, and land terminals were included as international trade operators. Customs norms establish that logistics service providers include customs dispatchers, transportation companies or their representatives, international freight forwarders, customs warehouses, and managers or concessionaires of ports, airports, or international land terminals. ${ }^{48}$ It should be noted that customs legislation aims at regulating operative aspects, infrastructure, IT, security, customs control, and guarantees for performing international trade activities, and not promoting the development of logistics service intermediaries.

As mentioned above, logistics operators are not directly regulated in Peru. Reflecting recent developments in the provision of logistics services at the international level, logistics operators in Peru are born from the integration of several logistics services; and they not only provide services for moving international trade cargo, but cover all their clients' operations. ${ }^{49}$ The services offered by logistics operators in Peru are: international trade, storage, cross-docking, transportation, distribution, and picking/packing. ${ }^{50}$

\footnotetext{
${ }^{47}$ Source: ASPPOR News.

48 Articles 15 y 45, Decreto Legislativo No. 1053 (General Customs Law).

${ }^{49}$ INTER-AMERICAN DEVELOPMENT BANK, MTC, ALG (2011), op. cit., p. 39, p.726.

50 These services are described in the PDSLT:
}

- International trade: similar to services provided by freight forwarders and customs agents.

- Storage: cargo receipt, inventory management, and dispatch. In contrast with intermodal terminals, logistics operators provide reference management and inventory services and report to the client, thereby facilitating decision-making. 
There are few operators of this kind in the Peruvian market; and the SME logistics base is insufficient for serving domestic production SMEs. In consequence, there is a substantial duplicity between large logistics operators catering to international trade, with multinational clients or large domestic companies; and low-quality, unspecialized small and medium logistics companies serving the domestic market. The 2011 Development Plan for Transportation Logistics Services (PDSLT) stresses that service specialization is limited, especially regarding the cold chain, picking/packing processes, and reference management at warehouses. ${ }^{51}$

A third category of barriers is the politically-determined "national priority" perception of logistics services. In a developing country, finding support for enhancing competitiveness in the provision of logistics services requires considerable political capital. For example, putting in place an aggressive trade policy, including free-trade agreements (FTAs) — to reduce import tariffsor bilateral transportation agreements (especially international transit arrangements) implies substantial political will at the domestic level.

\section{II.2. Norms regulating logistics service providers}

Regulations on logistics service providers are classified theoretically ${ }^{52}$ according to the following criteria: $:^{53}$

A. Market access: Norms on the requisites for entry of new operators into the market. In practice, such regulations aim at controlling the number of operators, protecting domestic operators against foreign competitors, and excluding operators that do not comply with professional quality standards.

- Cross-docking: in the case of fresh goods or goods from large distributors, cross-docking ensures a continuing merchandise flow and effective distribution. In this process, logistics operators are in charge of validating purchase and transport orders issued by their client; de-consolidating and consolidating cargo; generating waybills; and controlling the yield indicators (KPIs) established by clients.

- Transportation and distribution: similar to services offered by formal cargo transportation companies, with the difference that they are part of an operative design that is integrated with the rest of clients' operations and their supply chain.

- Picking y packing: selection and packing services, where logistics operators, through inventory management, condition the orders by selecting products and making the packings. They can also perform this activity in the client's facilities (in-house) using their personnel and knowledge.

(IADB-MTC-ALG, 2011, pág. 727)

51 INTER-AMERICAN DEVELOPMENT BANK (2011), op. cit., p.728.

52 This analysis is also performed by Kunaka, Mustra, and Sáez (Kunaka, Ch., Mustra, M., Saez, Sebastian, 2013, pág. 21); Claire Hollowed and Marn - Heong Wong (Regulatory Restrictions in Logistics Services, Chapter 4. Priorities and Pathways in Services Reform. Ed. Philippa Dee, 2013); and UNESCAP (UNESCAP, Guidelines for Minimum Standards and Codes of Professional Conduct for Freight Forwarders, Non-Vessel Operating Common Carriers and Multimodal Transport Operators, 2011)

${ }^{53}$ WATANUKI, M. (2015), op. cit. p. 7, pp. 7-8-9-10-11. 
Such regulations govern the following aspects:

a) Establishment:

$\circ$ Minimum capital and asset requirements.

○ Physical presence: a minimum staff —either local or legally established in the country - is required for operating.

○ Staff: some jurisdictions request a minimum qualification for managers; e.g., ten years' experience.

o Other requirements (an insurance policy as condition to apply for a license).

○ Discriminatory measures against foreign operators; e.g., more costly procedures for obtaining licenses; or the requirement of establishing joint ventures with local companies.

b) Scope of activities:

○ A different license for each logistics activity.

○ Limited scope and areas for performing activities.

- Foreign operators are forbidden to compete with local operators in certain activities.

Regulation is excessive in Peru, both at the central government and local level. In addition to the general norms governing each kind of international trade operators, the latter must obtain operating licenses from municipalities and comply with civil defines norms. It should be underscored that there are these kinds of requirements in each jurisdiction where logistics service providers operate.

The following chart shows the norms applying to international trade-related logistics operators:

Market Access Requirements for Logistics Service Operators in Peru

\begin{tabular}{|l|l|c|}
\hline \multicolumn{1}{|c|}{ Type of operator } & \multicolumn{1}{c|}{ Entity } & \multicolumn{1}{c|}{ Description } \\
\hline $\begin{array}{l}\text { Maritime, waterway, and } \\
\text { lake transportation }\end{array}$ & $\begin{array}{l}\text { Ministry of } \\
\text { Transportation and }\end{array}$ & $\bullet \quad$ Minimum social capital \\
\hline
\end{tabular}




\begin{tabular}{|c|c|c|}
\hline \multirow[t]{2}{*}{ agencies } & Communications & \\
\hline & $\begin{array}{l}\text { National Port } \\
\text { Authority }\end{array}$ & - Annually renewable license \\
\hline $\begin{array}{l}\text { Loading/unloading } \\
\text { companies; workers' } \\
\text { cooperatives }\end{array}$ & $\begin{array}{l}\text { National Port } \\
\text { Authority }\end{array}$ & $\begin{array}{l}\text { - Annually renewable license } \\
\text { - Minimum social capital } \\
\text { - Letter of guarantee and surety bond }\end{array}$ \\
\hline \multirow[t]{3}{*}{ Freight forwarders } & \multirow{2}{*}{$\begin{array}{l}\text { Ministry of } \\
\text { Transportation and } \\
\text { Communications }\end{array}$} & $\frac{\text { Maritime freight forwarders }}{\bullet \quad \text { Operating license }}$ \\
\hline & & $\begin{array}{l}\text { Air freight forwarders } \\
\text { - Operation conformity } \\
\text { - Security program } \\
\text { - } \text { IATA technical norms }\end{array}$ \\
\hline & Customs & $\begin{array}{l}\text { - Area of operations } \\
\text { - Data communication system; } \\
\text { computer equipment } \\
\text { - Security fire equipment }\end{array}$ \\
\hline Customs agents & Customs & $\begin{array}{l}\text { - Customs Agent License issued by } \\
\text { customs } \\
\text { - Legal domicile; residence in the } \\
\text { country } \\
\text { - Criminal record check; letter of } \\
\text { guarantee and surety bond } \\
\text { - Proof of personal property } \\
\text { - Minimum infrastructure (with } \\
\text { minimum exclusive space for dispatch } \\
\text { - Documents) } \\
\text { - Sata communication system; } \\
\text { computer equipment } \\
\text { Security fire equipment }\end{array}$ \\
\hline Customs warehouses & Customs & $\begin{array}{l}\text { - Only individuals or companies } \\
\text { established in Peru may apply for } \\
\text { authorization to operate customs } \\
\text { warehouses } \\
\text { - Comply with the necessary requisites } \\
\text { and conditions for operating } \\
\text { - Maintain an adequate level of } \\
\text { economic and financial solvency } \\
\text { - Implement security measures } \\
\text { - Provide a guarantee in favour of } \\
\text { customs } \\
\text { - Facilities dedicated exclusively to } \\
\text { warehouse operation and compliance } \\
\text { - } \text { with other special requirements } \\
\text { pocation at maximum distance from } \\
\text { - Merchandise storage and custody; } \\
\text { online connection with customs } \\
\text { TV camera monitoring system }\end{array}$ \\
\hline
\end{tabular}




\begin{tabular}{|l|l|l|}
\hline & $\begin{array}{l}\text { - } \\
\end{array}$ & $\begin{array}{l}\text { Record of not having been sanctioned } \\
\text { with cancellation due to non- } \\
\text { compliance with customs tax norms; } \\
\end{array}$ \\
& record of legal representatives not \\
& having been sentenced for \\
& committing intentional crimes \\
\hline
\end{tabular}

Access to the logistics markets is fairly open in Peru, with the following exceptions:

- Only individuals and companies established in Peru may apply for authorization to operate customs warehouses.

- The requirement to be domiciled and resident in the country creates an entry barrier to foreign operators in the customs brokerage business.

- Workers in charge of loading/unloading services must be Peruvian nationals.

B. Operations: Norms aimed at promoting the quality of logistics services to protect shippers and operators from unexpected accidents and incidents and prevent unfair competition.

a) Responsibility: logistics operators performing these kinds of services are exposed to considerable responsibility for merchandise loss/damage. In contractual practice, logistics service providers limit their responsibility via Standard Trading Conditions (STCs) and General Terms and Conditions (GT\&Cs). In this regard, FIATA has put in place norms governing freight forwarder services. ${ }^{54}$ Many clauses known as GT\&Cs are

54 PART II

THE FREIGHT FORWARDER'S LIABILITY

6. The Freight Forwarder's liability (except as principal)

6.1. Basis of liability

6.1.1. The Freight Forwarder's duty of care The Freight Forwarder is liable if he fails to exercise due diligence and take reasonable measures in the performance of the Freight Forwarding Services, in which case he, subject to Art.8, shall compensate the Customer for loss of or damage to the Goods as well as for direct financial loss resulting from breach of his duty of care.

6.1.2. No liability for third parties

The Freight Forwarder is not liable for acts and omissions by third parties, such as, but not limited to, Carriers, warehousemen, stevedores, port authorities and other freight forwarders, unless he has failed to exercise due diligence in selecting, instructing or supervising such third parties.

7. The Freight Forwarder's liability as principal

7.1. The Freight Forwarder's liability as Carrier

The Freight Forwarder is subject to liability as principal not only when he actually performs the carriage himself by his own means of transport (performing Carrier), but also if, by issuing his own transport document or otherwise, he has made an express or implied undertaking to assume Carrier liability (contracting Carrier). However, the Freight Forwarder shall not be deemed liable as Carrier if the Customer has received a transport document issued by a person other than the Freight Forwarder and does not within a reasonable time maintain that the Freight Forwarder is nevertheless liable as Carrier.

7.2. The Freight Forwarder's liability as principal for other services 
prepared by self-regulating professional associations; as such, they are not legally enforceable.

- Responsibility and its exceptions

○ Contractual terms and conditions

- Insurance coverage for performing operations

b) Experience, certification requirements and personnel training: Maika Watanuki mentions IATA and FIATA as examples of entities that organize courses to promote staff qualification in logistics, including the introductory course on cargo (known as the IATA Course) and IATA's course on hazardous merchandise. There is also a requisite course for obtaining a license to operate as air freight forwarder.

With respect to services other than carriage of Goods such as, but not limited to, storage, handling, packing or distribution of the Goods, as well as ancillary services in connection therewith, the Freight Forwarder shall be liable as principal:

1. when such services have been performed by himself using his own facilities or employees or

2. if he has made an express or implied undertaking to assume liability as principal.

7.3. The basis of the Freight Forwarder's liability as principal

The Freight Forwarder as principal shall, subject to Art. 8, be responsible for the acts and omissions of third parties he has engaged for the performance of the contract of carriage or other services in the same manner as if such acts and omissions were his own and his rights and duties shall be subject to the provisions of the law applicable to the mode of transport or service concerned, as well as the additional conditions expressly agreed or, failing express agreement, by the usual conditions for such mode of transport or services.

8. Exclusions, assessment, and monetary limits of liability

8.1. Exclusions

The Freight Forwarder shall in no event be liable for:

1. Valuables or Dangerous Goods unless declared as such to the Freight Forwarder at the time of the conclusion of the contract,

2. loss following from delay unless expressly agreed in writing,

3. indirect or consequential loss such as, but not limited to, loss of profit and loss of market.

8.2. Assessment of compensation

The value of the Goods shall be determined according to the current commodity Exchange price or, if there is not such price, according to the current market price or, if there is no commodity exchange price or current market price, by reference to the normal value of the Goods of the same kind and quality.

8.3. Monetary limits

8.3.1. Loss of or damage to the Goods

The provisions of Art. 7.3. notwithstanding, the Freight Forwarder shall not be or become liable for any loss of or damage to the Goods in an amount exceeding the equivalent of 2 SDR per kilogram of gross weight of the Goods lost or damaged unless a larger amount is recovered from a person for whom the Freight Forwarder is responsible. If the Goods have not been delivered within ninety consecutive days after the date when the Goods ought to have been delivered, the claimant may, in the absence of evidence to the contrary, treat the Goods as lost.

8.3.2. Limitation of liability for delay

If the Freight Forwarder is liable in respect of loss following from delay, such liability shall be limited to an amount not exceeding the remuneration relating to the service giving rise to the delay.

8.3.3. Other type of loss

The provisions of Art. 7.3. notwithstanding, the Freight Forwarder's liability for any type of loss not mentioned in 8.3.1. and 8.3.2. shall not exceed the total amount of ....... SDR*) for each incident unless a larger amount is received from a person for whom the Freight Forwarders is responsible.

FIATA MODEL RULES FOR FREIGHT FORWARDING SERVICES

http://fiata.com/uploads/media/Model_Rules_07.pdf 
- Professional certification issued by local and international associations

○ Professional training requirements for logistics personnel

c) Service quality control: a number of self-regulatory bodies e.g., the Singapore Logistics Association contribute to professionalization within the industry by issuing best practice manuals for the logistics industry. For its part, the European Logistics Association (ELA) promotes competence standards in the industry.

○ Operative manual for the industry

○ Establishment of standards and criteria for logistics services

d) Dissemination of information: regulation required to promote transparency and fair competition within the industry.

○ Publication of service tariffs and charges

○ Report on efforts to mitigate negative environmental impacts.

One of the main shortcomings identified in Peru, partially due to an outdated legal framework, is that the government fails to introduce and monitor a set of appropriate standards. The control of logistics service providers lies mostly with Peruvian customs. The lack of technical requirements results in high informality in most operators. This in turn induces regulators to adopt measures tailored for companies operating on the brink of illegality, which is seriously detrimental to companies complying with all legal norms and international standards.

In Peru, there are no business associations or government entities dedicated to promote the observance of quality standards and the general terms and conditions for the provision of logistics services. Neither is it common practice to comply with commercial standards. Moreover, as mentioned above, logistics service tariffs are not published despite the legal obligation to do so, thereby hampering information transparency and dissemination within the industry.

It is imperative for logistics operators to reach international standards like their peers providing such services at the global level. Appropriate government or self-regulation is key to achieving this goal.

The following chart summarizes the operative requirements for international trade operators: 
Operative Requirements for Logistics Service Providers in Peru

\begin{tabular}{|c|c|c|}
\hline Type of operator & Entity & Description \\
\hline $\begin{array}{l}\text { Maritime, waterway, } \\
\text { and lake } \\
\text { transportation } \\
\text { agencies }\end{array}$ & $\begin{array}{l}\text { National Port } \\
\text { Authority }\end{array}$ & $\begin{array}{ll}\bullet & \text { Annual license renewal: } \\
\checkmark & \text { Annual activity report } \\
\checkmark & \text { Letter of guarantee and surety bond }\end{array}$ \\
\hline $\begin{array}{l}\text { Loading/unloading } \\
\text { companies; workers' } \\
\text { cooperatives }\end{array}$ & $\begin{array}{l}\text { National Port } \\
\text { Authority }\end{array}$ & $\begin{array}{l}\text { - Annual license renewal: } \\
\text { - Annual activity report }\end{array}$ \\
\hline \multirow[t]{3}{*}{ Freight forwarders } & \multirow{2}{*}{$\begin{array}{l}\text { Ministry of } \\
\text { Transportation and } \\
\text { Communications }\end{array}$} & $\frac{\text { Maritime freight forwarders }}{\text { - No clear regulations in place }}$ \\
\hline & & $\begin{array}{l}\text { Air freight forwarders } \\
\text { - Delivery of information to inspectors } \\
\text { - Compliance with Peru's aeronautical } \\
\text { regulations, approved safety program, } \\
\text { and any other activity associated with } \\
\text { aviation safety }\end{array}$ \\
\hline & Customs & $\begin{array}{l}\text { - Keep documentation and registers } \\
\text { during five (5) years } \\
\text { - Stay in communication with customs } \\
\text { - Facilitate enforcement of customs } \\
\text { control measures } \\
\text { - Provide, publish, or deliver the } \\
\text { necessary information or } \\
\text { documentation } \\
\text { - Appear before customs authorities } \\
\text { - } \text { Keep customs books, registers, and } \\
\text { documents } \\
\text { - Submit cargo manifests to customs; } \\
\text { rectify or add documents to cargo } \\
\text { manifests }\end{array}$ \\
\hline Customs agents & Customs & $\begin{array}{l}\text { - } \text { Keep documentation and registers } \\
\text { - } \text { during five (5) years } \\
\text { - } \quad \text { Facilitate enforcement of customs } \\
\text { control measures } \\
\text { - } \quad \text { Provide, publish, or deliver the } \\
\text { necessary information or } \\
\text { documentation } \\
\text { - Appear before customs authorities } \\
\text { - } \text { Khen summoned } \\
\text { - documents } \\
\text { - } \text { Update information on personal or } \\
\text { Annual renewal of guarantee }\end{array}$ \\
\hline
\end{tabular}




\begin{tabular}{|c|c|c|}
\hline & $\begin{array}{l}\text { Superintendence of } \\
\text { Banks, Insurance } \\
\text { Companies, and } \\
\text { Private Pension Funds } \\
\text { (SBS) }\end{array}$ & $\begin{array}{l}\text { Provide customs agents with } \\
\text { information that may contribute to } \\
\text { preventing money laundering } \\
\text { - Keep an updated register of operations } \\
\text { for amounts greater than or equal to } \\
\$ 10,000\end{array}$ \\
\hline Customs warehouses & Customs & 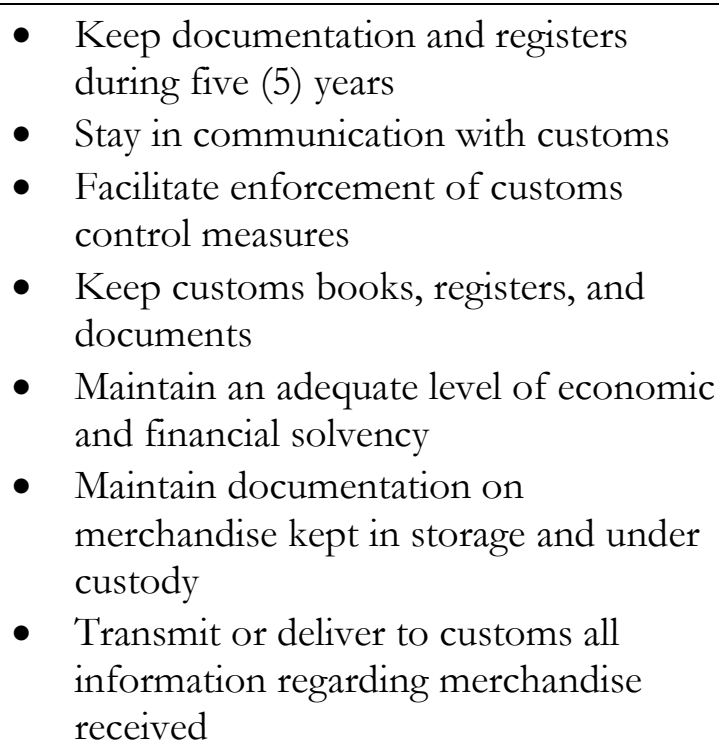 \\
\hline
\end{tabular}

\section{II.3. Barriers to logistics service providers}

There are different approaches to the obstacles faced by logistics operators. In preparing its Services Trade Restrictiveness Index (SRTI), the OECD assesses a wide range of barriers to the provision of logistics services. ${ }^{55}$

In particular, Peru's logistics market faces the following restrictions:

\section{II.3.1 Barriers to free competition}

Restrictions to competition may create disincentives to foreign operators seeking to invest in the logistics market. They include the presence of state-controlled companies exempted from freecompetition legislation. The lack of dispute settlement and appeal mechanisms is considered by the OECD as an obstacle to free competition. Furthermore, if the entity in charge of managing airports, ports and other trade-related facilities provide handling services, they can create

${ }_{55}^{5}$ SUGIE, K. ET AL. (2014) Services Trade Restrictiveness Index (SRTI): Logistics Services. OECD Trade Policy, p. 9. Papers No. 183, OECD Publishing, Paris. 
inconveniences to other providers of the same services. Regulations that confine the operation of logistics services to a specific geographic area are also considered within this category. ${ }^{5657}$

In Peru, there is a controversy between providers and users of port/airport services regarding restrictions to free competition. The studies commissioned to look into the matter concluded that overuse of terminals outside the port area creates a structural over-cost to Peru's international trade sector. ${ }^{58}$ Moreover, certain users claim for free competition in the provision of such services and transparency in the tariffs charged.

On several occasions INDECOPI has reviewed anti-competition practices in the provision of logistics services. A complaint was submitted to INDECOPI's Commission for the Defence of Free Competition regarding certain practices in the market for air cargo storage services, namely that two companies strongly concentrate the provision of storage services for cargo unloaded at Jorge Chávez International Airport (over 80\% of imports since 2001). Both companies have exclusive operation contracts with most airlines, which makes it difficult for other companies to compete in that market. Moreover, they combine storage services with ground handling and

\footnotetext{
${ }^{56}$ Ibidem, p. 13.

${ }^{57}$ Regarding competition in the provision of port services, the OECD mentions several practices that could result in a dominant position:
}

- Excessive prices: establishing prices deemed excessive, as it bears no relation with the economic value of the product offered.

- Refusal of services: it could happen when a port with a dominant position (e.g., maritime lines operate or own their own terminals within a port) refuses to provide a service. This level of integration between companies could create incentives for limiting access only to their clients. This case was subject to investigation by the Italian free competition authority.

Problems against free competition may be resolved through mediation by the relevant authorities. In the case of abuse of a dominant position regarding infrastructure, a possible solution is to divide the components of the relevant market. In the case of prices, the solution may imply regulation of the prices under question.

In the European Union, the European Commission's General Directorate for Competition, the national competition authorities, and national courts have investigated the port industry. Particularly, the main problem in cases against free competition at ports, as established before the Commission and the Court of Justice, was related with the difficulties in accessing services within ports. In the U.S., the Federal Maritime Commission (FMC), an independent federal agency, is the relevant authority for reviewing and managing all practices and agreements by MTOs (logistics operators), as established by the Shipping Act. These kinds of agreements must be submitted to the FMC; and 45 later they may be exempted from the Antitrust Act, unless the FMC alleges before a court that they obstruct free competition, reduce the provision of transportations services, or increase costs beyond what may be deemed reasonable. This mechanism for administrative-judicial review of whether logistics operators and users of their services affect free competition has resulted in few judicial cases.

Within the region, a case involving practices against free competition by logistics operators took place in Chile in 2003. In this case, Chile's Exporters Association (Asoex) filed a complaint for concerted pricing, abuse of dominant position, abusive prices, and arbitrary discrimination against customs brokerage agencies. Asoex's main argument was the concerted imposition by shipping agents of charges for services that had not been requested by the exporters. In this case, the Court for the Defense of Free Competition, through sentence No. 38/2006, ruled that the shipping agencies had incurred in abuse of dominant position.

58 The reports by Martín Sgut (2005), Edgardo Gamarra (2006) and the Port Modernization Consortium (Consorcio de Modernización Portuaria, 2011) are examples of this current of opinion. 
passenger checking. Storage services are paid for by consignees, who ultimately end up subsidizing the airlines. ${ }^{59}$

In principle, consignees may choose the storage terminal (temporary storage) where they want their merchandise to remain in storage until it is retired. However, in practice, airlines choose Cargo Terminals (Points of Arrival) — precisely those that provide air cargo loading/unloading services - where cargo is delivered to consignees or to the temporary warehouses chosen by them. The complainant argued that this manner of operation would be correct if the cargo was delivered free of additional costs. However, cargo terminals charge the consignees for the services contracted by the airlines. This practice was denounced by the complainant as a market entry barrier for providers of temporary storage services that do not have contracts with airlines. ${ }^{60}$

Despite the arguments submitted, the Commission declared that there were no grounds for a complaint on alleged abuse of a dominant position in the modality of price discrimination. (Resolución No. 002-2005-INDECOPI/CLC).

Regarding the port service market, in 2015 a complaint was submitted before the Commission for the Defence of Free Competition on allegations of practices to restrict competition by certain maritime agents and storage terminals. One of the main arguments in the complaint was that maritime agencies and intermodal terminals had acted in collusion to levy excessive charges for their services, charge for non-existent services, and pass on to users certain obligations due to be paid by shipping lines. Finally, Resolución No. 008-2010/CLC-INDECOPI declared this complaint inadmissible and unfounded.

\section{II.3.2 Regulatory Transparency}

This category includes regulations on publication and communication of norms and licensing regimes, as well as procedures for requesting and renewing licenses. The main barriers are excessive processing times, costs, and documentation required. ${ }^{61}$

\footnotetext{
59 The complainants' arguments are explained in "El mercado de almacenamiento aduanero en el terminal aéreo del Callao", a report produced by Universidad del Pacífico and entered into the "Actualidad de Transparencia Logística" blog on June 26, 2013. The blog was consulted on May 2, 2016. http://transparencialogistica.blogspot.pe/2013/06/adextemas-operacion-aeroportuaria.html

60 "El mercado de almacenamiento aduanero en el terminal aéreo del Callao" (study produced by Universidad del Pacífico).

${ }^{61}$ SUGIE, K. ET AL. (2014), op. cit. p. 28, p. 13.
} 
As noted above, while no studies could identify any infringement of free competition in either maritime or air cargo services, INDECOPI has invariably ruled against the lack of transparency in the prices charged for port and airport services. This led to the enactment of the International Trade Facilitation Law (Ley No. 28977), which established the creation of an MTC website containing information on port and airport service companies; i.e., the content and prices of services provided by port and airport operators. ${ }^{6}{ }^{2}$ However, to date the website had not yet been implemented.

\section{II.3.3 Restrictions to the movement of physical persons}

These regulations limit the temporary movement of persons from one country to another. They are part of mode 4 of the General Agreement on Trade in Services (GATS) regarding the movement of physical persons from a Member to the territory of another Member with the purpose of providing a service. Such barriers include restrictions on the number of foreign professionals authorized to work, conditional on tests for economic necessity or quotas; and norms establishing that nationals from a given country can only provide logistics services. ${ }^{63}$

In Peru, contracts with foreign workers are regulated by the Law on Contracting Foreign Workers (Decreto Legislativo No. 689, recently modified by Decreto Legislativo No. 1246 and its bylaw, Decreto Supremo No. 014-92-TR). This legislation establishes, as a general principle, the preference for contracting domestic workers; and indicates that contracting foreign workers is subject to the following limitations:

- The number of foreign employees may not exceed $20 \%$ of the total number of employees.

- Wages paid to foreign workers may not exceed $30 \%$ of the total payroll.

Exemptions to the above limits include the contracting of specialized professional or technical personnel, directors/managers of new companies, and other similar cases.

${ }^{62}$ Ley No 28977, Ley de Facilitación de Comercio Exterior (International Trade Facilitation Law): Article 10.- Publication of the content and prices of port and airport services 10.1 A free-access information module will be created within the MTC website containing information on companies providing port and airport services. It will include information on the services, content, and prices; and will be submitted monthly to the National Port Authority and the MTC's General Directorate for Civil Aviation.

${ }^{63}$ SUGIE, K. ET AL. (2014), op. cit. p. 28, p. 12. 
Foreign workers may be contracted for a maximum of three years (renewable) with approval by the Labour Administrative Authority.

\section{BEST PRACTICE IN THE PROMOTION OF LOGISTICS SERVICE PROVIDERS}

This section describes the best practice in legislation, action plans, and implementation of public policies for promoting the development of logistics service providers. Public sector participation should aim at creating a favourable business climate for attracting global logistics service providers to the domestic market; and promoting quality standards in the provision of domestic logistics service providers via partnerships with global peers. Public policy should also encourage the provision of specialized logistics services by SMEs to promote job creation and competition in the logistics industry. The experiences in today's main regional arrangements are presented next.

\section{III.1 Asia-Pacific}

This is the regional space where the most advanced public policies for promoting logistics services have been implemented. It includes highly developed economies (China, South Korea, and Japan) focused over the last 20 years on gaining greater access to the global supply chain.

The People's Republic of China gradually adopted measures for liberalizing the logistics sector, encouraging foreign investment in domestic logistics companies; promoting the development of 3PLs and the consolidation of domestic operators; improving the business environment; enhancing infrastructure; and establishing common IT standards and applications. In 2011 the Chinese government announced its 20th Five-Year Plan, which emphasized the following aspects: establishing a modern logistics system, based on social principles and IT; putting in place an aggressive policy for promoting 3PLs; reinforcing the construction and interconnection of logistics infrastructure; improving logistics efficiency; reducing logistics costs; promoting logistics improvement in agriculture, mining, and key industries; and seeking a balanced logistics development throughout the country by establishing logistics parks and improving standardization and technology. Notably, the plan also considered promoting outsourcing logistics services, which benefits the multiplication and strengthening of 3PLs. 
Regarding public policies for promoting logistics services in China, the document known as “The State's Nine Guidelines" establishes the goal of reducing costs via the reduction of taxes and charges. The strategy included identifying inconsistencies between tax rates levied on storage, distribution, cargo, and transportation companies. A study was also ordered about taxation of land used for storage of commodity cargo. ${ }^{64}$ Additionally, the Guidelines consider facilitating the logistics industry's access to lands, markets, and financing; establishing preferential arrangements for using lands to build logistics parks; reducing, subject to certain regulatory conditions, the requirements for approving qualifications; and encouraging logistics companies to perform intra-regional operations.

Moreover, the Guidelines establish financial support to large logistics companies for building transportation, storage, distribution, and IT facilities (including improvements in financial mechanisms and investment in the logistics industry). ${ }^{65}$

The Guidelines also mandate the following measures for improving logistics practices:

- Support logistics companies in consolidating resources through mergers, acquisitions, cooperation arrangements, or partnerships.

- Assist commercial circulation enterprises in performing distribution operations jointly with large companies.

- Establish supportive tax and employment policies for encouraging large manufacturing companies to abandon their logistics assets and operations.

- Encourage logistics companies to increase the technological component in the supply chain and IT platforms.

South Korea's good practice norms for logistics service providers are laid out in the National Logistics Basic Plan (2011-20), which establishes the following three public policy goals: a) ensuring the value added of overall logistics; b) putting in place a comprehensive logistics system; and c) reinforcing the competitiveness of domestic logistics companies. The following strategies were proposed for fulfilling these goals: a) attracting global parent companies from northeast Asia; b) developing a new business model within an integrated zone in northeast Asia; c)

\footnotetext{
${ }^{64}$ LI, KENA. (2014). Policies and Plans on China's Logistics Development, p. 55, en B.-l. Liu et al. (eds.), Contemporary Logistics in China: Consolidation and Deepening, Current Chinese Economic Report Series, DOI 10.1007/978-3-642-34525-8_4, Springer-Verlag Berlin Heidelberg 2014.

${ }^{65}$ Ibidem, p. 57.
} 
improving and establishing the capacity to provide services; d) encouraging logistics companies to provide services in foreign markets; and e) expanding the domestic market for logistics services. ${ }^{66}$ A Presidential Committee was appointed to attract global logistics corporations that can offer a high volume of services in the Korean market. Phase 1 of the strategy (2005-09) prioritized expanding the market for 3PLs to create economies of scale and promote the emergence of companies providing integrated logistics services. During Phase 2 (2010-14), the strategy focused on establishing logistics companies to serve the regional Pacific Basin market. Phase 3 (starting 2014) aims at empowering Korean logistics companies to compete with their global counterparts. ${ }^{67}$

With an aim to promote competitiveness among domestic logistics providers, since 2006 the Korean government has focused on measures to provide integrated logistics services. Along these lines, the government enacted the Integrated Logistics Industry Certification Act to assist logistics service providers in operating in a specialized and differentiated manner. ${ }^{68}$ The certification system included benefits such as the right to occupy a space in logistics facilities; expanding such facilities; and obtaining loans, incentives for accessing foreign markets, and tax benefits. ${ }^{69}$ The Act envisages a global logistics network; supports global logistics providers that can integrate logistics services; aims to create international-quality logistics providers; and promotes a business model that seeks service diversity with a long-run perspective. In sum, Korean logistics service providers (global logistics companies, freight forwarders, maritime lines, and land transportation companies) must provide integrated logistics services beyond the basic ones; and their business must expand into the international market. The Korean government's policies aim at facilitating the entry into the market of at least 2-3 of the 20 best global logistics service providers by 2015 and $1-2$ by $2020 .^{70}$

The Framework Act on Logistics Policies considers measures to improve logistics efficiency via standardization, cooperation, and information dissemination. Moreover, it introduces norms for encouraging competitiveness, training personnel, and internationalizing the industry; ${ }^{71}$ and promotes 3PLs via financial support to companies that outsource logistics services in favour of

${ }^{66}$ RIMMER, P. (2014), op. cit. p. 5, p. 313.

${ }^{67}$ Ibidem, p. 300.

${ }^{68}$ PARK, H. Y LEE, Y. (2015). The Efficiency and Productivity Analysis of Large Logistics Providers in Korea. The Asian Journal of Shipping and Logistics, p.p. 469-470. http:/ /dx.doi.org/10.1016/j.ajsl.2016.01.005

${ }^{69}$ Ibidem, p. 475.

${ }^{70}$ Ibidem, p. 470.

${ }^{71}$ UNESCAP (2013) Guide to Key Issues in Development of Logistics Policy. [Libro en línea]. Division of Transport, p.p. 38-39. [Consultation: February 15, 2017] Available at: http://www.unescap.org/sites/default/files/Logistics_policy_fulltext.pdf)., op. cit., p. 17. 
3PLs. It also includes a certification mechanism for logistics companies providing transportation, storage, and value-added services; and regulates entry/exit of international freight forwarding via enforcement of minimum standards (register, minimum capital, insurance, and criminal record check). Notably, the Act emphasizes the need to develop human capital in the logistics industry and establishes guidelines for capacity-building programs. Finally, it envisages administrative and financial support for establishing a Logistics Association.

The National Logistics Master plan proposes measures for promoting 3PLs, such as introducing tax reductions and consultancy services; seeking outsourcing of logistics within public entities in favour of 3PLs; and establishing certification for companies able to operate globally, with an aim to encourage the internationalization of Korean logistics companies. ${ }^{72}$

Japan provides important examples of best practice in this field. The updating of the Comprehensive Logistics Policy 2001-2005 mentions specifically the development of logistics service providers. Towards the beginning of the century, Japanese 3PLs have experienced a considerable transformation via partnerships, mergers, and acquisitions. Additionally, in response to recent catastrophe events, Japanese manufacturing and distribution industries have begun to establish agreements with companies connected to international supply chains.

This new policy approach to the provision of logistics services emphasizes reducing requirements for market entry, reinforcing capacity building in this field, and encouraging both the expansion of domestic logistics companies and the entry into the Japanese market of global logistics service providers. Finally, it proposes strategies for further developing multimodal transportation, promoting privatization, putting in place incentives for the grouping of logistics companies, deregulating the market for freight forwarders, and eliminating restrictions to the entry of new warehouse operators into the market. ${ }^{73}$

Regarding the remaining countries in the region (Indonesia, Malaysia, Thailand, Laos, and Vietnam), two aspects can be highlighted. First, is necessary to create the basic conditions for promoting the logistics industry (currently at the same stage of development as Peru). Second, these countries have a differentiated strategy for developing logistics services (the "soft" dimension of logistics), usually overlooked by most countries in favour of logistics infrastructure.

\section{III.2 European Union}

\footnotetext{
72 Ibidem, p. 47.

${ }^{73}$ RIMMER, P (2014), op. cit. p. 5, p.p. 237-238.
} 
In Europe, the design of public policies for promoting the logistics sector is permeated by a concern to prevent negative social impacts (congestion, noise pollution, and $\mathrm{CO}_{2}$ emissions, among others).

In Germany, the Federal Ministry of Transportation, Construction, and Urban Development submitted an Action Plan for Cargo Transportation and Logistics - Logistics Initiative for Germany at the end of 2010. The plan aimed at establishing a concrete development strategy for reinforcing Germany's position as a major international logistics centre, with emphasis on sustainability. Its main goals are the following:

- Reinforce Germany's position as a logistics centre.

- Improve efficiency in all transportation modalities.

- Exploit the advantages of all transportation modalities via an optimal interconnection of transportation infrastructures.

- Ensure compatibility between increased traffic and measures to protect the environment and address climate change.

- Support best labour practices and capacity building in the cargo transportation industry.

In sum, the Plan's goal is to ensure the German market's position as a first-level global logistics centre.

The Action Plan for Cargo Transportation and Logistics - Logistics Initiative for Germany emphasizes the excellent quality of German logistics service providers. One of the Plan's main concerns regarding logistics services and their providers is the promotion of basic and continuous capacity building in the logistics sector.

The initiative was updated jointly by the Federal Ministry of Transportation and Digital Infrastructure and the private sector in 2016 via the Action Plan for Cargo Transportation and Logistics - Towards a Sustainable and Efficient Future. The Federal Government's agenda focuses on three key areas. Regarding investment, the government envisages taking transportation infrastructure to an all-time high. To this end, investment in structural maintenance and infrastructure improvement in the transportation industry will increase $40 \%$ by 2018. Second, the industry will be modernized via efficiency innovations such as alternative truck 
drivetrains and longer vehicles. The initiative's third pillar is greater digitalization to increase bandwidth in rural areas and innovation in automated and connected driving systems.

The strategy for marketing Germany as a logistics centre is the result of a cooperation between the logistics industry and the federal states via the "Logistics Alliance Germany" (LAG) agreement. Besides the German government (through the Federal Ministry of Transportation and Digital Infrastructure), LAG is formed by large, medium, and small logistics companies and the main trade associations for all transportation modalities. LAG organizes international fairs and trips to emerging and European markets (e.g., Brazil, Russia, India, China, and South Africa) and other promotional activities. Essentially, LAG aims at raising awareness of the need to strengthen Germany's position as a logistics centre and reinforce its image as a provider of high quality logistics services. $^{74}$

The "Smart Logistics in the Netherlands" plan prepared by the Dutch Science and Technology Office aims at positioning the country as a strategic logistics platform and turning it into Europe's leader in merchandise control and coordination by $2020 .^{75}$

The guidelines' proposal is to focus on knowledge-intensive logistics by creating, developing, demonstrating, and applying new practices in managing the large-scale supply chain. This change is expected to increase value added and efficiency in processing the international merchandise flow.

The initiative led to the formation of an independent association for promoting logistics ("Nederland is Logistiek") and a public entity (the Holland International Distribution Council) for enhancing Dutch companies' participation in the international supply chain. The government also introduced the "Lean \& Green" program for providing financial assistance and certifications to companies that reduce their $\mathrm{CO}_{2}$ emissions. ${ }^{76}$

\footnotetext{
${ }^{74}$ FEDERAL MINISTRY OF TRANSPORT AND DIGITAL INFRASTRUCTURE -GERMANY- (2016) Freight Transport and Logistics Action Plan - Towards a Sustainable and Efficient Future. Published by Federal Ministry of Transport and Digital Infrastructure. First update, June 2016, p. 8. Recuperado 10/2/17

http://www.bmvi.de/SharedDocs/EN/publications/freight-transport-logistics-actionplan.pdf?_blob=publicationFile

${ }^{75}$ NETHERLANDS OFFICE FOR SCIENCE AND TECHNOLOGY (2013) Smart Logistics in the Netherlands, p. 4. Recuperado 13/2/17. https://www.rvo.nl/sites/default/files/2013/11/Smart\%20Logistics\%20(ENG).pdf ${ }^{76}$ COMITÉ SCIENTIFIQUE (2015) Conférence nationale sur la logistique La logistique en France. État des lieux et pistes de progres Rapport du comité scientifique présidé par Michel Savy. Rapport établi avec le concours du ministère de l'Écologie, du Développement durable et de l'Énergie, du ministère de l'Économie, de l'Industrie et du Numérique, et de la Commission nationale des services. Mars 2015, p. 48. Downloaded 02/10/17. http://www.ladocumentationfrancaise.fr/var/storage/ rapports-publics/154000199.pdf
} 
The Netherlands aim at building a "golden triangle" (i.e., a public-private partnership between the private sector, universities, and the government) via the Dinalog (Dutch Institute for Advanced Logistics), established at end-2009 to stimulate innovation in logistics and supply chain management. Dinalog's ultimate goal is to preserve long-run logistics competitiveness in the Netherlands. ${ }^{77}$

\section{III.3 Pacific Alliance}

Peru can benefit highly from the experience of its Pacific Alliance partners since, besides geographic proximity, the latter are at a similar stage of development regarding economic conditions and public logistics policies.

Colombia's 2008 National Competitiveness and Productivity Policy ${ }^{78}$ considered logistics among its 15 action plans as a key competitiveness and productivity component and recommended putting in place a specific logistics policy. This led to the preparation of a National Logistics Policy (PNL), ${ }^{79}$ which established guidelines in areas like institutionality, information production, and logistics infrastructure.

A central element in the plan was emphasizing the need to improve information for designing, implementing, and monitoring progress in PNL implementation via a National Logistics Survey, a logistics observatory, and better information on road cargo transportation.

Chile's Transportation Sub-Secretariat is the logistics administration authority. Chile's Logistics Master Plan was preceded by the Maritime Program (2009-2010), the Logistics Development Program, and the creation of the Logistics Development Division (2014). The Logistics Development Program resulted from the Transportation Sub-Secretariat's mandate to assume leadership in planning all cargo transportation systems, with a view to enhancing their role as a key competitiveness element. ${ }^{80}$ Since 2014, the Logistics Development Division leads a prioritized and consistent public logistics initiative. The cross-industry priority guidelines for that year were establishing a logistics observatory (in cooperation with the OECD's International

\footnotetext{
77 NETHERLANDS OFFICE FOR SCIENCE AND TECHNOLOGY (2013), op. cit. p. 37, p. 5. f

78 Documento Conpes 3527 (2008): Política Nacional de Competitividad y Productividad. Downloaded 02/17/17. http://www.colombiacompetitiva.gov.co/sncei/Documents/Conpes-3527-de-2008.pdf

${ }^{79}$ Documento Conpes 3547 (2008): Política Nacional Logística. Downloaded 02/17/17. http://www.colombiacompetitiva.gov.co/sncei/Documents/Conpes-3527-de-2008.pdf

${ }^{80}$ Ministry of Transportation and Telecommunications of Chile. Logistics Development Division. Website consulted 12/05/16. http://www.mtt.gob.cl/pdl.html.
} 
Transport Forum); putting in place social assessment methodologies (such as measuring the value of time in freight transportation); establishing Port Community Systems for state-run Comex port companies (including interaction with SICEX); building border crossings with Argentina; setting in motion a program for supporting logistics competitiveness and innovation in partnership with the Production Promotion Corporation (CORFO); and preparing the Logistics Master Plan (implemented in 2015-16). ${ }^{81}$

The program for supporting competitiveness and innovation in the logistics industry is managed by CORFO in direct coordination with the Ministry of Transportation.

The vision that guides the Logistics Development Program ${ }^{82}$ is "achieving world-class logistics systems for fostering economic development". 83 Its mission is "promoting a continuing improvement of Chile's foreign trade and domestic competitiveness by introducing comprehensive cargo transportation policies/projects and ensuring their implementation." It sits on the following four pillars: ${ }^{84}$

- Capacity: ensure adequate infrastructure facilities for a fluent cargo movement within the country.

- Competition and Competitiveness: promote a continuing improvement in logistics performance as a source of competition and competitiveness, as well as in documentary management.

- Professionalization and Modernization: secure an attractive, dynamic, and modern cargo transportation industry.

- Reduction of Externalities: achieve a close interaction between cargo transportation transit and the cities where it takes place.

It should be noted that the program's management approach is differentiated by transportation modality: maritime, ports, railways, roads, and special projects. The report by the Commission

\footnotetext{
${ }^{81}$ MICHEA, A. (2014) Anexo 6: Programa de Desarrollo Logístico de Chile. Alexis Michea, General Coordinator, in “Taller sobre Transporte de Carga y Logística”, August 5-6, 2014, Lima, Peru. Downloaded 02/13/17. http://www.iirsa.org/admin_iirsa_web/Uploads/Documents/taller_tsp_lima14_Log\%C3\%ADstica_\%20MTT_chi le.pdf

82 Document available on http://productos.nexsa.cl/cpi2016/wpcontent/uploads/2016/11/PROGRAMA_DE_DESARROLLO_LOGISTICO.pdf

83 TRANSPORTATION SUB-SECRETARIAT-CHILE (2014) Planificación Estratégica Programa de Desarrollo Logístico. March 2014, p. 3. Downloaded 02/15/17 https://www.mtt.gob.cl/wpcontent/uploads/2013/12/PROGRAMA_DE_DESARROLLO_LOGISTICO.pdf ${ }^{84}$ Ibidem, p. 3.
} 
for the 2030 Strategy on Ports and their Logistics confirmed this approach, with emphasis on the logistics and port system.

In Mexico, the background instruments regarding public logistics policies are the National Development Plan 2007-2012 (PND), the National Infrastructure Program 2007-2012 (PNI), and the Ten Guidelines for Enhancing Competitiveness 2008-2012. PND and PNI proposed facilitating domestic and international trade by promoting more efficient logistics services that could secure a competitive, sufficient, and timely supply of production inputs to companies. It is worth noting that the eighth guideline proposes positioning Mexico as a distribution hub for IT services. $^{85}$

The above guidelines provided the foundation for the Logistics Competitiveness Agenda 20082012, aimed at developing world-class logistics services in Mexico with a view to enhancing competitiveness via policies for improving service quality. The goals considered are the following: ${ }^{86}$

- Improving the quality and predictability of the operative logistics system within the supply chain.

- Enhancing the quality of the services offered by Mexican logistics companies.

- Implementing policies for establishing lasting relations among suppliers and clients within the supply chain.

This instrument also aimed at creating the conditions for developing better logistics services at competitive costs and adopting logistics best practice among companies established in Mexico. ${ }^{87}$

In 2013, a consultancy study was commissioned to define a national system of logistics platforms and an implementation plan. While it focuses on the analysis of the country's logistics infrastructure, it also emphasizes the need to reinforce logistics institutionality. ${ }^{88}$

\footnotetext{
85 INDUSTRY AND TRADE SUB-SECRETARIAT-MEXICO (2008) Agenda de Competitividad en Logística 20082012. April 2008, p. 4. Downloaded 02/13/17 http://www.chihuahua.gob.mx/atach2/dircomercio/uploads/AGENDA\%20LOGISTICA\%202008(2).pdf

86 Ibidem, p. 5.

${ }^{87}$ Ibidem, p. 46.

88 INTER-AMERICAN DEVELOPMENT BANK, COMMUNICATIONS AND TRANSPORTATION SECRETARIAT AND ECONOMY SECRETARIAT OF MÉXICO. (2013). Definition of a national system of logistics platforms and implementation plan, p. 57. Downloaded 02/10/17. http://www.elogistica.economia.gob.mx/swb/work/models/elogistica/Resource/12/1/images/ResEjecProyectoS NPLM $\%$ C3\% $\% 3 \%$ C2\%A9xico.pdf.
} 
The Logistics Competitiveness Agenda 2008-2012 provides a diagnostic for the supply of logistics services in Mexico. A main shortcoming in the logistics industry is that outsourcing has not developed as expected. In this regard, the agenda points to the following as main limitations: low diversification in logistics services; deficient relations among logistics service providers (caused by declining service quality, increasing costs, and higher operating times); a limited use of environment-friendly logistics services; a lack of logistics performance indicators; security issues affecting all transportation modalities; limited IT use by SMEs; and a lack of financing for implementing projects to improve logistics. ${ }^{89}$

The Agenda stresses that the main challenges for improving the supply of logistics services are achieving an adequate diversification and identification of the domestic logistics industry; implementing logistics performance indicators; providing adequate support for developing logistics projects; and adopting innovative technological systems. ${ }^{90}$ Other shortfalls include inadequate quality certification of logistics services; a scarcity of logistics professionals; and a lack of public-private coordination. ${ }^{11}$

It also includes seven strategic alternatives, some of which seek to strengthen the provision of quality logistics services in Mexico. The strategies considered for enhancing logistics services include providing adequate statistical information on the performance of logistics companies; improving relations between participants in the service supply chain; and supporting the outsourcing of specialists in logistics services, among others. ${ }^{92}$ Additionally, it is proposed to promote the adoption of logistics best practice by disseminating information on the support to logistics projects and the benefits of implementing logistics best practice; implementing measures for stimulating the study and understanding of the logistics culture; promoting the dissemination of successful experiences in the logistics supply chain at the local, national, and international level; re-launching the National Logistics Price; and supporting the implementation of workshops on benchmarking of logistics processes and supply chain management for large companies and SMEs. Finally, strategies 5 and 6 aim at encouraging the certification of logistics operators and promoting capacity building in the field of logistics services. ${ }^{93}$

The Logistics Competitiveness Agenda 2008-2012 was followed by the "Diagnóstico Net Anáhuac en Logístik" Internet portal (www.dnalogistik.com), aimed at assessing and improving

\footnotetext{
${ }^{99}$ INDUSTRY AND TRADE SUB-SECRETARIAT-MEXICO (2008), op. cit. p. 39, p. 41.

${ }^{90}$ Ibidem, p. 42.

${ }^{91}$ Ibidem, p.p. 51-52.

92 Ibidem, p.p. 47-48.

93 Ibidem, p. 47.
} 
companies' logistics via consultations with experts and providing appropriate methods and tools. The website provides companies with knowledge about their logistics processes; compares processes vis-à-vis best practice; offers logistics blueprints for adding value; identifies optimal logistics options; and provides capacity building for developing logistics projects. ${ }^{94}$

Additionally, a seal of approval for logistics processes was established. This certification aims at verifying, supporting, and promoting best practice throughout the supply chain and the services offered by companies established in Mexico. ${ }^{95}$

Peru must examine exhaustively all national experiences in the Asia-Pacific region. The largest economies in the region (China, Japan, and South Korea) were the first to recognize logistics as a central element within public policy design, as reflected by the preparation of their national logistics plans. The establishment of public-private institutional bodies for designing policies and plans, and for monitoring their implementation, is an experience Peru should consider adopting. Moreover, those countries have put in place specific legislation for developing logistics service providers, notably by encouraging partnerships between large domestic logistics operators and international logistics conglomerates; and by encouraging foreign investment in the industry.

It is also worth emphasizing the wide range of incentives for the logistics industry: tax benefits, subsidies, preferential logistics zonification, and special credit regimes, among others.

A good practice that Peru would be well advised to adopt is a quality certification system for logistics providers, such as in South Korea (and other countries like Singapore and Mexico) managed by a business associations or government entity.

Peru should design its logistics plan after Indonesia's phased model. As suggested by the Andean Promotion Corporation (CAF), Peru's logistics plan should not aim directly at becoming a regional hub. The first step would be to strengthen its National Logistics System (SLN) before moving on to the domestic, sub-regional (Andean Community, CAN), and regional (Pacific Alliance) levels. Once on the last stage, Peru could attempt to connect with global logistics networks.

\footnotetext{
94 HERNÁNDEZ CASANOVA, R (2011) Politicas Públicas para el desarrollo de la Logística y la Gestión de la Cadena de Suministro en México. "Seminario Internacional de la Logística: hacia un plan nacional de competitividad". Presented in Buenos Aires, Argentina, September 22, 2011, p.p. 16-18. Downloaded 02/15/17. http://www.mecon.gov.ar/peconomica/dnper/documentos/MX_RHernandez_Politicas_Publicas.pdf 95 Ibidem, p. 24.
} 
Germany and the Netherlands can provide a model for establishing a national logistics trademark. In Peru (which has the experience of successfully positioning a national trademark) it would contribute significantly to raising awareness on the need to promote a national logistics industry. Establishing universities and research institutes specialized in logistics could help to address the lack of qualified $\mathrm{Hs}$ in the industry. Finally, logistics public policies should consider environmental, congestion, and noise pollution issues.

Peru could also learn from the experience of its Pacific Alliance partners. For instance, Colombia addresses the lack of reliable logistics information (a problem affecting the region as a whole) by conducting a national logistics survey. Chile's Port Community Systems model should be adopted by Peru, as well as competitiveness and innovation support programs. Mexico's certification of logistics operators, Internet portal for disseminating microeconomic logistics knowledge, and seal of approval for logistics processes should also have a place in Peru's logistics agenda. All three countries are currently implementing Logistics Observatories, still a pending task in Peru.

Summing up, all country cases reviewed consider two prioritary components: modernizing infrastructure; and resolving inadequate capacities and raising interest in logistics jobs.

\section{PROPOSALS FOR DEVELOPING LOGISTICS SERVICE PROVIDERS IN PERU}

\section{IV.1 Institutionality}

Based on an assessment of Peru's considerable infrastructure deficits, the SLN seeks to promote public logistics policies under a phased, gradual approach. It is advisable to start by designing and implementing strategies addressing the "soft" component of logistics processes, namely logistics institutionality. An initial "rapid victory" in implementing the "soft" component would encourage significantly the development of logistics infrastructure. It is worth emphasizing that the "soft" component of logistics is not as onerous as material goals such as building and

\footnotetext{
96 "Rapid victories" are short-run projects requiring considerable organization and control, and resulting in an effective impact. Presentation by Maravillas Rojo in La Antigua, Guatemala, July 11-15, 2011. Consulted January 28, 2017. https://issuu.com/cideu/docs/victorias_rapidas
} 
maintaining logistics infrastructure. A strong drive in developing logistics services will likely create an incentive for implementing the "hard" component, namely logistics infrastructure. In sum, addressing logistics services should provide leverage for phased SLN rollout.

While institutionality has been largely overlooked, it is of critical importance. Building an institutional structure would be instrumental in providing the industry with much-needed commitment. Notably, many entities at the local and regional level do not participate in coordinated policy efforts for promoting logistics and facilitating trade. As proposed by the 2014 Medium- and Long-Term Development Plan for Transportation Logistics Services (PMLP), ${ }^{97}$ empowering a logistics entity at the highest political level (e.g., responding directly to the President of the Council of Ministers) would align the public sector as a whole towards implementation of the required changes. Another benefit from an appropriate political umbrella is providing an effective communication channel between the public and private sectors, which would legitimize the agenda at the national, regional, and local level; and serve to convey assistance in corporate practices to the public sector. Moreover, the initiative should be supported by a Technical Secretariat, i.e., a mixed technical team formed by international, regional, and academic entities. The latter would be crucial for presenting the strategic goals to the High-Ranking Committee. It could also contribute with guidelines and HRs for establishing a public-private partnership aimed at promoting innovation and dissemination of logistics best practice (ideally modelled after the Netherland's Dinalog).

Another issue to be addressed is private sector representation in the proposed institutional arrangement. There is great atomization and disparity among the business associations that could potentially participate in the initiative. A number of logistics service providers do not participate actively in business associations; and, while the main logistics operators are located in Lima, many others operate in other Peruvian towns. Finally, debates within business association are traditionally harsh.

The objectives and plans of the proposed institutional arrangement should include strengthening logistics service providers. In the view of the author of this study, it makes no difference whether these objectives and plans are legally enacted; but it is essential to put in place the necessary monitoring and financing mechanisms for ensuring that logistics operators comply with global industry standards.

${ }^{77}$ INTER-AMERICAN DEVELOPMENT BANK, MINISTRY OF TRANSPORTATION, AND ALG (2014) Plan de Desarrollo de los Servicios Logísticos de Transporte Plan de Mediano y Largo Plazo. [online], August 2014, pp. 66-67. [Consulted February 10, 2017]. Available on: https://www.mtc.gob.pe/estadisticas/files/estudios/PMLP_MTC $\% 20$ Versi $\%$ C3\%B3n\%20Final.pdf 
The first step towards building the necessary SLN institutionality is establishing it by law.

As indicated above, the first legal step should be to enact a framework law for logistics development. The second one would be to issue a norm for regulating comprehensive logistics service providers (ideally denominated 3PLs in line with international practice).

\section{IV.2. Sectoral Logistics Policy}

\section{IV.2.1 Building Awareness of Logistics Operators' Role as Service Exporters}

It is necessary to address the lack of awareness about the importance of building a robust logistics industry in Peru. The notion that logistics service operators are "service exporters" is not firmly established in the country. It is paradoxical that, on one hand, there is much talk in Peru about the goal of becoming a regional logistics hub and, on the other hand, there is no discussion about how to develop logistics service providers. In sum, despite the urgent need to resolve logistics shortcomings in Peru, a task that involves both infrastructure and service issues, there are no public policies that consider logistics services as service exports.

Peru's successful experience with launching a country trademark provides a valuable foundation for designing policies to enhance visibility of the logistics industry. In this regard, the German and Dutch experiences with creating a country logistics trademark should be examined carefully by the relevant authorities.

\section{IV.2.2 Comprehensive regulatory treatment of logistics service providers. Significant streamlining of red tape affecting the operations of logistics operators.}

Peru should avoid the current fragmented approach to the regulation of logistics service providers; e.g., regarding customs. The fragmented customs regulation of international trade operators resulted from the traditional model for the provision of such services and, especially, its main interest; i.e. preserving fiscal revenues. It is possible to consider the possibility of regulating a comprehensive logistics operator to expedite the flow of goods in the supply chain without losing effectiveness in customs control. As mentioned above, considering logistics 
service providers as exporters of Peruvian services will likely have a positive impact on its regulatory framework.

However, MTC and Port Authority legislation is outdated and should simply be eliminated to avoid confusions in this field.

Taking the establishment of a Peruvian logistics trademark as a starting point, it is possible to conceive a comprehensive logistics service provider in the country. Fortunately, as Peru already enjoys a favourable business climate for foreign direct investment, the remaining work should focus on market access requirements and operations control. A regulatory framework geared to promote development should be rational, establish a limited number of efficient control entities, and put in place efficient controls to ensure appropriate operation. In this regard, like in Panama, it is advisable to create a Single Window for Logistics Service Providers to centralize and facilitate the issuance and renewal of licenses and authorizations; and use the opportunity to eliminate those that are effective in practice.

For a proper functioning of the Single Window, the government would have to facilitate authorizations for land use, the assessment of environmental impacts, and the issuance of occupancy and constructions permits.

At the Single Window, logistics operators could submit a single guarantee covering all kinds of contingencies that may be detrimental to the government's interests. This would reduce the costs created by the various guarantees that currently must be submitted to a number of government entities. Dealing with a single government authority (which would avoid over-regulation and reduce compliance costs) would be a considerable incentive for current operators and an excellent signal for potential participants.

Yossi Sheffi ${ }^{98}$ underscores that urban planning should not be left out of a process of administrative streamlining. The government can either facilitate or inhibit private investment in logistics clusters, depending on its approach to authorizing land use, mandating environmental impact assessments, and issuing occupancy and construction permits.

${ }^{98}$ SHEFFI, Y. (2014) Clústeres Logísticos. Brindando valor e impulsando el crecimiento, p. 177. Buenos Aires: Temas Grupo Editorial S.R.L. 


\section{IV.2.3 Adoption of international standards in the domestic logistics market.}

Currently Peru does not have a quality certification system in this industry. Neither are there general clauses for contracting logistics service providers nor any mechanism for distributing responsibilities between a comprehensive operator and cargo owners. This process can only be addressed via a business association recomposition within the logistics industry. Asian countries that have succeeded in promoting logistics service providers have used either self-regulation (Singapore) or government regulation (China) for enforcing compliance with industry standards. In order to prosper, logistics business associations must put in place appropriate quality standards for service provision; and countries relying to a greater extent on self-regulation should ensure enforcement of adequate non-compliance sanctions. Credibility is key to successful implementation of the latter kind of model.

\section{IV.2.4 Incentives for promoting the domestic logistics industry}

\section{IV.2.4.1 Logistics market growth}

One of the first steps for promoting such services is creating a domestic logistics market that may be attractive enough to induce global service providers to increase their investments in the Peruvian market; encourage large domestic logistics operators to expand their operations; drive Peruvian SMEs to specialize in providing services to specific market niches; and incentivize small Peruvian logistics enterprises to formalize their activities. International experience suggests that certain tax incentives for large companies that outsource logistics can contribute to expanding the market for logistics services. These policies deserve careful examination, including the fiscal cost of such incentives.

\section{IV.2.4.2 Promoting the entry of global logistics operators into the Peruvian market}

Peru should facilitate market access to large global logistics operators as a mechanism for promoting knowledge transfer to domestic logistics companies. At the same time, it is advisable to open the market in a phased manner, so as not to affect domestic logistics providers. As in Korea and Japan, it should be a national goal to target a number of global providers entering the domestic market. 
In line with the need to transfer global practices and standards from global to domestic operators, the government should promote concentration within the logistics service industry. However, it is worth noting that, from past experience, it is necessary to ensure that this kind of corporate consolidation will not hamper competition. An active participation of SMEs, to be promoted through financial and tax incentives, could be instrumental in offsetting such trends.

\section{IV.2.4.3 Credit and tax measures}

Peru does not apply any kind of industrial policy; therefore, the only way to promote logistics service providers would be to use targeted tax and financial incentives. Sheffi mentions the following policies: loans tied to innovation, tax drawback schemes, and measures for expediting the adoption of new practices, cargo transportation technologies, and ICT, which would promote emission reduction, streamline transportation requirements, enhance efficiency in transportation, and reduce costs. ${ }^{99}$ The author emphasizes that governments typically try to attract logistics companies via a wide range of incentives, such as land purchase subsidies, temporary tax reductions, loan guarantees, and preferential treatment schemes. ${ }^{100}$

Such policies deserve close consideration in the design of policies for promoting domestic logistics SMEs, mainly by enhancing their competitiveness in catering to niches within Peru's logistics market. Mexico provides an example of the benefits from a more microeconomic approach; e.g., creating a portal and an entity dedicated to enhancing SME competitiveness.

The only tax benefit is the exemption from the VAT for the export and import of cargo transportation services. However, logistics services are not included in the list of operations considered as service exports. In response to the lack of transparency in the tax treatment of logistics services, SUNAT issued a report to clarify that logistics services could be considered as "business support services" (which are considered service exports):

\footnotetext{
${ }^{99}$ CLECAT Y FIATA (2014) Joint Position Paper. Role of Freight Forwarders and Logistics in Intermodal Chains. Position on the UNECE Workshop on the Role of freight forwarders and logistics in intermodal transport chains. June 2014, p. 5. Downloaded 02/10/17. http:/ fiata.com/fileadmin/user_upload/documents/Position_Papers/Role_of_freight_forwarders_and_logistics_i n_intermodal_transport_chains.pdf.

${ }_{100}$ SHEFFI, Y. (2014), op. cit. p. 46, p. 179.
} 
"... an operation may be considered as a service export if it is possible to verify that

it is a service provided within the country to companies or users located abroad; and

if it implies supporting users' business activities." 101

A critical way of supporting the logistics industry would be to include logistics services comprehensively as a service export so it qualifies for the VAT drawback scheme.

\section{IV.3. Capacity building and promotion of specialized HRs}

It is essential to address capacity building in the logistics industry. Whether through a publicprivate entity or a cooperation agreement between education entities, the country must ensure the participation of an adequate number of specialized workers and managers. It is urgent to implement a national education plan geared for the logistics industry.

\section{FINAL CONSIDERATIONS}

Given its geographic location within South America, Peru is considered as a potential regional hub. However, reaching that goal requires designing and implementing a comprehensive logistics policy.

Promoting logistics services in the country includes, notably, enhancing logistics infrastructure. While promoting logistics service providers is not overly costly, it requires introducing a new institutional framework, rationalizing the legal framework, and putting adequate incentives in place.

This study aims to assist policy-makers by reviewing the international experience with best practice in developing logistics service providers.

A Law on the Development of Logistics Service Providers would provide a public-private institutional framework that would in turn contribute to introducing action plans and, fundamentally, facilitating their implementation and monitoring. Finally, systematic regulation of logistics service providers will contribute to attracting investment and establishing an appropriate incentive scheme for the logistics industry. $\begin{array}{lllllll}101 & \text { CARTA } & \text { No. } & \text { 067-2015-SUNAT/600000, Lima, October 28, } & 2015 . & \text { Available } & \text { on } \\ \text { http://www.sunat.gob.pe/legislacion/oficios/2015/informe-oficios/c067-2015.pdf } & & & \end{array}$ 